\title{
Confesión sacramental y psicoterapia Una aproximación teleoanalítico-transaccional acerca de la fe cristiana, el pecado, el secreto y la reconciliación
}

\author{
Sacramental confession and psychotherapy \\ Teleoanalytical-transactional approach to the Christian faith, \\ sin, secret and reconciliation
}

Iván Maurial Chávez ${ }^{1}$

\section{RESUMEN}

En el presente artículo reflexiono acerca de la confesión tal como se realiza en la comunidad cristiano-católica. En la descripción del fenómeno, pretendo ser objetivo, al margen de mis propias creencias explícitas acerca del tema. En determinados momentos, interpreto y, por lo tanto, adopto una postura amable o crítica acerca del modo de realización del sacramento. También realizo observaciones desde la psicología y la psicoterapia sobre temas de fe. Dios, demonio, culpa, pecado, arrepentimiento, conversión y perdón. El recurso a la enseñanza del magisterio de la Iglesia romana es básicamente documental y no responde a un interés apologético. El uso de citas bíblicas tiene por objetivo la mejor aproximación al mensaje cristiano, siendo consciente de los riesgos que ello implica, considerando que se trata de manuscritos transcritos en tiempo distinto con diferencia de estilo literario en cada autor veterotestamentario y judeo-cristiano. El análisis transaccional y la psicología teleoanalítica, son formas de psicología en clave adleriana que permiten comprender el fenómeno religioso, reconociendo las actitudes y el significado de conductas en el sacerdote confesor como en el penitente. Finalmente, argumento en favor de la inclusión de herramientas terapéuticas de fondo lúdico que pueden facilitar de modo significativo el proceso de cambio y de crecimiento personal de los creyentes teniendo en cuenta el significado de sus propios símbolos de reconciliación con la totalidad o idea de la verdad, en este caso, Dios.

\section{Palabras clave}

Análisis transaccional, confesión sacramental, fe cristiana, pecado, secreto, teleoanálisis adleriano.

\section{ABSTRACT}

This paper was a reflection on the confession as it is carried out in the Christian-catholic community. The phenomenon was described in an objective way, regardless of any explicit beliefs on the subject. At certain moments, a kind or critical stance was interpreted and, therefore, adopted towards the way the sacrament is carried out. Moreover, some observations were made from the psychology and psychotherapy view about faith, God, demons, guilt, sin, remorse, conversion and forgiveness. The use of training teachers of the Catholic Church was essentially for documentary purposes and does not respond to apologetic interests. The use of biblical quotes aimed at getting a better approach to the Christian message, being aware of the risks involved in such endeavor since manuscripts were transcribed in a different time and with the diverse literary style of each Old testament and Judeo-Christian author. The transactional analysis and the Teleoanalytical psychology are forms of psychology in Adlerian code, which enables to understand the religious phenomenon, recognizing the attitudes and the meaning of conducts both in the priest

Psicólogo, escritor y psicoterapeuta. Docente en la Facultad de Psicología y Humanidades de la Universidad Femenina del Sagrado Corazón. 
confessor and in the penitent. In the end, there was some arguing in favor of including therapeutic tools with ludic background, which may facilitate significantly the process of change and personal growth of believers, considering the meaning of their own symbols of reconciliation with the whole or the idea of truth, in such case, God.

\section{Keywords}

Transactional analysis, sacramental confession, Christian belief, sin, secret, adlerian teleoanalysis.

\section{Experiencia "religiosa" (amorosa), culpabilidad universal y confesión sacramental}

La experiencia religiosa está vinculada al hecho de vivir en un mundo imperfecto donde error, enfermedad y muerte constituyen aquella trama por la cual se desplaza el optimismo del yo en la vida cotidiana. Confesar confiadamente algo en sentido sacramental es ya poner en marcha una serie de mecanismos psicológicos que nos protegen del peligro que va incluso más allá de la muerte física. Queda el sujeto protegido de toda muerte simbólica que es básicamente vivir en desamor. Por medio del amor estamos vinculados profundamente con el mundo. Dicho afecto configura una vida motivada y llevadera. Cuando no da suficiente alegría otorga sosiego. La experiencia de paz cristiana no es simplemente tranquilidad y contento. La paz que se describe en el plano místico-religioso es una vivencia extraordinaria de plenitud que va más allá de cualquier sentimiento gratificante del ego individual. Con ella se puede superar toda imperfección incluida la muerte en su forma física. El cristiano cruza un par de palabras con Cristo y recupera la paz que busca y que no es como aquella del mundo (Juan 14: 27; 2 Tesalonicenses 3: 16).

La confesión tiene un carácter catártico en tanto produce descarga de emociones. Contar aquello que significa algo nuclear para la recuperación de la tranquilidad del yo individual en secreto es ya el despliegue satisfactorio de energía corporal. Es, además, transformación de la comunicación con quien escucha mientras representa a un Otrocomunidad (Cristo como imagen del Padre y el Espíritu Santo). Lo indebido confesado es recibido y guardado para siempre. El otro indiviso con su fe (el sacerdote) y el Otro-tri- unidad (Dios) se vuelven parte de la oración. El yo reposa contento y entiende que Dios le ha "per-donado" (Dios-Comunidad insiste en él) porque, a pesar de todo, lo ama. En el amor divino queda el hombre religado misteriosamente a lo creado y todo lo que Dios ha creado es bueno. El individuo queda desenmascarado en el amor incondicional $y$ en donde el único "infierno" (inferioridad) es insistir en su propia imagen del "personaje bueno" en una película para los demás, pero que a solas no puede dar cara a quien tanto denomina "su Dios". Solo cuando se pone a un lado el personaje (bueno o malo) del yo individual es posible dejar a Dios ser Dios. Entonces aparece la experiencia de paz en sentido sobrenatural y la alegría de compartir la propia experiencia de "ser perdonados" (amados incondicionalmente).

La confesión, en sentido cultural y éticoreligioso es anterior a como se conoce en el cristianismo católico. Otras religiones del pasado también incorporaron la confesión al trato con la divinidad (Widengren, 1976). La idea que subyace a estas manifestaciones de corte religioso pueden deberse a un sentimiento primigenio de inferioridad ante el hecho mismo de existir. Hay un carácter imperativo en la vida misma desde el momento en que no decidimos haber nacido para la muerte. Entendemos que la inferioridad en sentido religioso puede adquirir la forma de culpabilidad, prototipo de la creencia en el "pecado original". La experiencia del yo individual que tanto se afirma en nuestro tiempo no estaba tan arraigada en otras formas de experimentar la realidad. El pecado de uno afecta al todo que es humanidad. La cultura, a través de medios no-verbales (subconscientes) muestra cómo el yo individual debe desaparecer para ceder el paso a la comunidad cuando no solo procura 
crear formas de protección civil (instituciones) y religioso (templos de culto) sino que construye monumentos para todo sujeto particular que ha dedicado su vida al arte, el conocimiento y la fe en beneficio de la humanidad. El héroe, el santo, el genio y el artista son íconos de toda la humanidad porque se entiende que sobrepasan los intereses del ego individual. La cultura refuerza la muerte simbólica y física solo si es favorable al todo colectivo.

La tradición cristiano-católica presenta siete rituales de salvación que son signos eficaces de gracia. Los ritos sagrados son formas de expresión de tipo bisagra que por medio de símbolos permiten el encuentro (el abrazo) entre Dios y el hombre, entre lo sagrado y lo mundano. No se trata sólo de una serie de rituales que hace un sacerdote en frente del creyente sino de una experiencia profunda de confianza y gratitud por parte del hombre ante la cercanía de Dios en la propia vida: "Los sacramentos son símbolos, son expresión de la vida y la vida se concentra en los sacramentos" (Díaz Mateos, 1996 p. 112). En este sentido para el cristiano, "Cristo es el sacramento primordial, lugar privilegiado del encuentro y de la presencia del Dios invisible" (Ibíd. p. 113). Para el creyente, la confesión sacramental "simboliza" un encuentro, no en sentido de algo que solo se representa como escenificación ni mero movimiento sino como expresión del perdón divino mediante la absolución luego del arrepentimiento.

\section{Conciencia moral como expresión del núcleo del yo}

Cuando el individuo obra en contra de lo que es debido, se enfrenta a la propia conciencia moral que se ha ido sofisticando desde la "configuración temprana del psiquismo" (niñez) y, desde entonces, hay un componente afectivo que condiciona sus actos, actitudes y gestos, expresando con ello el "modo de comprenderse a sí mismo y a los demás" (posición existencial). Cada acto, incluso el que consideramos trivial, es un medio para conocer lo importante de la propia "construcción singular" (yo) que se puede entrever por medio del conocimiento de preferencias, creencias y de la congruencia reflejada en cada hecho en relación a su contexto. El tejido fundamental del yo es "normatividad" (herencia cultural) y "genes" (herencia biológica), tejido complejo en el caso del ser humano porque, a diferencia de cualquier otro organismo vivo, está marcado por la voluntad libre que implica relativo control sobre la estimulación medioambiental en la medida que puede "atribuir significados derivados de un consenso cultural sobre la materia" (percepción).

La conciencia es la capacidad de responder al estímulo medioambiental. Aquí, "respuesta" se opone a la "reacción". Respuesta implica la acción consciente y voluntaria del yo que puede hacerse responsable de sus actos. En este sentido, "responder" es conducta y "reaccionar" es actividad inconsciente en el sentido de dinamismo biológico o "comportamiento" en su sentido más preciso. En la conducta el sujeto puede tener el manejo de su actividad y "responder por ella" (responsabilidad). Esta facultad de la consciencia es evidente luego de describir los niveles de su desenvolvimiento: "conciencia" como "darme cuenta" y "conciencia refleja", como "darme cuenta de que me doy cuenta" que ya es una capacidad específicamente humana. La conciencia refleja que acompaña el desarrollo del autoconcepto y de la autoestima trae consigo el germen de un sentido de la libertad y, por tanto, de responsabilidad que denominamos conciencia moral: "darme cuenta de que debo dar cuenta". La conciencia moral es lo más íntimo del sujeto; sin embargo, en su forma de realización, se ubica, paradójicamente, fuera del sujeto. No se puede entender nuestra conducta ética sin los demás. Incluso nuestra "buena conducta" y nuestra propia "autoimagen" necesitan, desde un inicio, de la opinión ajena. La norma es inicialmente foránea hasta que se "incorpora".

Con lo antedicho, estamos reconociendo que la actividad humana es ética en la medida que implica acciones libres en las cuales cada sujeto puede ser en alto grado responsable. Cuando obramos en contra de lo que consideramos injusto, podemos tener actitudes semejantes a un animal a quien atribuimos "arrepentimiento" por haber desobedecido una orden. La protoemoción básica del perro es de miedo al castigo de su amo y por eso muestra la cabeza 
inclinada, mira en diagonal como evitando encontrar la mirada del dueño, mientras tanto mueve tímidamente la cola que se mantiene en dirección hacia el suelo. Tal reacción se mantendrá hasta que el dueño se muestre benévolo. El animal tiene muy pocas opciones de respuesta distinta ante el estímulo a diferencia de lo que ocurre en el sujeto que tiene consciencia refleja. El humano, no procede únicamente por temor al castigo, también puede actuar éticamente, con capacidad para reconocer por qué y para qué responderá ante el "estímulo" (situación). Cuando hace algo incorrecto puede enmascararlo. $\mathrm{Su}$ plasticidad conductual es tal que incluso le es posible negarse a sí mismo la realización de tal o cual hecho que considera malo con tal de no experimentar el dolor de la culpa. En ese sentido, el humano es "él y su máscara" porque para su realización exige no siempre ser mirado: el hombre en cada acto es, aun dentro de su espontaneidad, un ser fundamentalmente discreto.

No solo se trata de enmascaramiento ante los demás, sino, sobre todo, ante sí mismo. El humano está condicionado por sus percepciones a ver lo que le sirve para confirmar sus hipótesis acerca de la vida. La acción de reproche que ha interiorizado ya desde muy temprano (en la conducta verbal y no verbal de las personas importantes de referencia) puede ser muy potente a la hora de intentar una descripción sincera acerca de sí mismo. Convirtiendo el yo como si fuese una esfera, las capas más profundas y nucleares de esta serían equivalentes al núcleo del núcleo. Dicho "centro personal" es "lugar" de la conciencia moral que en realidad es la conciencia íntima de libertad que proviene de lo que en el cristianismo desde su influjo griego se denomina "alma". En psicología, para dar cuenta de aquello que la religión señala, recurrimos a un término que adquiere diferentes acepciones según la teoría de procedencia: el "sí mismo". Nosotros nos valemos del término "sí mismo personal" que se describe en la fenomenología de Lersch (1974) para quien el término "yo" es solo un recurso conceptual.
El sí mismo personal (el "yo mismo") se puede interpretar como fuente invisible de juicios y voluntad libre. No lo podemos definir claramente pero está presente en todo acto comunicativo como interlocutor y como "uno mismo" dueño de sus experiencias que está viajando de presente en presente consciente, como yo ahora, que estoy consciente que soy el mismo que hace instantes. La experiencia del sí mismo puede variar según el estado de conciencia y las circunstancias que vive el individuo. Allport (1986) ha dedicado un espacio de su estudio a la conciencia del sí mismo y sus modos de conocimiento.

\section{Aproximación a la conciencia moral religiosa en clave neo-adleriana}

Alfred Adler fue de los primeros terapeutas que se dedicó a la psicoterapia en términos de educación. La niñez no era vista en términos de "perversión" sino parte del "desarrollo creativo". Adler concibe al individuo libre como totalidad habilitada en función de su tendencia finalista. El adulto sano fue aquel niño a quien se le enseñó a involucrarse con los demás. El déficit del "sentimiento comunitario" (que solo se vive en el mundo consciente) es ya una forma de ingresar en el ámbito de la "neurosis". El niño que experimenta profundos sentimientos de inseguridad se aferra a la "meta ficticia de seguridad absoluta" (inconsciente) alejándose así de su potencial sentido de comunidad. Es posible que en el intento natural de compensación, que todo humano tiene para el progreso socializado, se "sobrecompense" buscando ideales de perfección ajenos al sentido común que serán percibidos desde la "sana razón" del mundo adulto como "desadaptados", "patológicos" e "inmorales".

La psicología individual adleriana nos acerca al territorio de lo sagrado por medio del tema del "sentido de la vida" (Adler, 1970). Para Adler "vivir es evolucionar". Nuestra aspiración a la perfección solo puede concebirse desde una conciencia de "déficit" y gracias a esa situación de inferioridad es que todo va de menos a más. La psicología adleriana se presenta en principio como atea pero reconoce que el "sentimiento de comunidad" es aquello que más nos humaniza y se debe 
a los primeros hombres que se reunieron con la fantasía de vida en el más allá que simboliza justamente la aspiración inconsciente del humano hacia la perfección imposible que se hace especialmente viable por medio de la religión. Las desviaciones de la personalidad hacia la conducta que el sentido común no tolera es una forma inauténtica de alcanzar la perfección que procura la superioridad sobre los demás afirmando el yo propio sin considerar que se es parte del todo colectivo que aspira a permanecer para siempre.

En teoría, la enseñanza cristiana está acorde con la psicología del desarrollo infantil cuando nos habla de la importancia de potenciar el sentido de comunidad y de la necesidad de coherencia de las figuras significativas en el tema del cariño potente y nutricio que es la base para que un niño pueda tener respuestas más satisfactorias con su prójimo. Por el mismo camino se desplazan las investigaciones de René Spitz y Harry Harlow. Para Viktor Frankl la culpa es el reconocimiento de haber hecho inadecuado uso de nuestra libertad. Antes que el sentimiento morboso de autocastigo se trata de "sentido de responsabilidad". Libertad y conciencia del otro van de la mano, de tal forma que, para Frankl, libertad y responsabilidad son caras de la misma moneda: Somos libres para ser responsables.

La vertiente de la psicología de Alfred Adler denominada Teleoanálisis adleriano fue creada por Michael Titze (1983). Propone que la dimensión inconsciente de la personalidad puede interpretarse como un "Sistema primario de referencia" (Hazán y Titze, 2011) que se gesta durante los primeros años de vida y su característica principal es que se maneja bajo el principio de la "lógica afectiva". Esta interpretación es plausible porque el niño construye su propia imagen y la imagen del mundo apoyado en experiencias emocionales con muy vaga presencia de las exigencias de la vida adulta donde, en cambio, las referencias de la acción tienen el sello del sentido común y de la norma social y moral. El sistema primario de referencia se guía, por lo tanto, por el principio de placer, tal como lo describe Freud. Desde la pubertad en adelante el individuo va desarrollando el sistema consciente y verbal que Titze denominará "Sistema secundario de referencia" (Hazán y Titze, 2011) que orienta al individuo en función de normas de conducta que, en última instancia, pueden estar inscritas en la moral religiosa que procura una igualación de los sujetos como parte de la "comunidad" de creyentes a quienes se les dicta normas de conducta fundamentales que en muchos casos resultan muy lejanas de los intereses del sistema primario de referencia.

Para Titze, cada sistema de la personalidad opera de modo complementario estableciendo un equilibrio tal como lo hacen el sistema simpático y parasimpático en el ámbito biológico. Durante la infancia, solemos frenar el adecuado despliegue del sistema primario por medio de estructuras familiares rígidas y poco democráticas que junto a otros factores contextuales fomentan el desarrollo "rígido" (legalista) o laxo (permisivo) del sistema secundario. La norma inadecuadamente introyectada promueve una personalidad rígida y tendente al "pensamiento extremista", como ya denunció en su tiempo Albert Ellis (1990). Para el teleoanálisis, las personalidades obsesivo-compulsivas son la expresión más clara de cómo una persona fue instruida para abultar el sistema secundario en el sentido de "sobresocialización" caracterizada por una sed de evidencia y exactitud que termina afectando la capacidad del sujeto para errar mientras se encierra en un círculo vicioso de perfección que nunca puede alcanzar y cree que alcanzará mediante el cumplimiento puntual y exagerado de la norma.

Por el contrario, la exacerbación de las conductas desde el sistema primario puede ponerse de manifiesto en individuos que la psicopatología describe como "antisociales", en donde la configuración del sistema secundario suele ser permisivo (laxo) en la vida privada y, por el contrario, exigente con los demás. El sujeto no se compromete, además lo hace con la intención de "hacer daño" a otros (mentira, cinismo, triunfo maligno, ansia de poder, carencia de sentido de culpa), por eso suele ser apartado de la sociedad que se maneja en función del "sentido común" que es fundamentalmente normativo. El sujeto llamado vulgarmente "psicópata" se convierte 
en la expresión máxima del sujeto "malo", "perverso" y "endemoniado", contrario al sujeto calificado como "bueno", "virtuoso" y "santo" que está dentro del ideal de conducta del sujeto que se mueve dentro del marco del sistema secundario. A diferencia del psicopático, un yo "neurótico" será para el teleoanálisis aquel individuo con seria dificultad para socializar por dificultad de convergencia de las finalidades de cada sistema de referencia. Hecha esta descripción, veo oportuno poner de relieve la representación de la conciencia moral en Titze, antes que todo porque su concepción de equilibrio de sistemas (normativo y hedonista) y finalidades no privilegia el dominio de lo consciente sobre lo inconsciente o viceversa. Con ello está señalando que la psicoterapia contemporánea aun siendo beneficiosa y rica en herramientas de cambio, sigue modelos limitados con relación a la dinámica de la conciencia.

El Análisis Transaccional de Eric Berne es una escuela de psicoterapia psicodinámica de elevado coeficiente integrativo. Se lo define como escuela de "ciencias de la conducta" (Junchaya, 1985; Kertész, 2010) que estudia el comportamiento humano en función de tres sistemas de comunicación. El Análisis Transaccional representa el desarrollo de la conciencia moral por medio de su esquema estructural de segundo orden en donde cada estado del yo (Padre, Adulto y Niño) tiene subestados. La síntesis creativa de Berne puede entenderse como originada en las plataformas del psicoanálisis de Sigmund Freud, sobre todo, en el planteamiento de un estado del yo Padre que puede recordar al "súper yo" $y$ en el estado del yo Niño que se aproxima en varios aspectos al "ello" freudiano. Sin embargo, cuando vemos el desenvolvimiento del individuo dentro del esquema funcional y de la mayoría $\mathrm{de}$ instrumentos transaccionales, es posible identificar más la deuda de Berne para con Adler. Por eso, creo conveniente situar el Análisis Transaccional dentro del enfoque neoadleriano en donde también ingresaría un grupo amplio de psicoterapeutas como Erik Erikson, Harry Sullivan, Viktor Frankl y Albert Ellis, por ejemplo.

La representación transaccional tiene la virtud de facilitar el reconocimiento de cómo se aprenden diálogos internos que promueven la rigidez conductual en la comunicación de la edad adulta. Este enfoque de terapia también explica cómo es que se establece la acentuación de un sistema de referencia y cómo es que el individuo va construyendo su propio esquema de referencia privado para dar cumplimiento a la meta ficticia de seguridad perfecta (Adler) y en donde Berne ve el "guion inconsciente de vida". Este guion $\mathrm{o}$ argumento promueve conductas dependientes (agresoras o sumisas) que el sentido común, con influjo de la psiquiatría y la religión, denomina "trastornadas", "perversas", "pecadoras" o "malvadas". El desarrollo del Análisis Transaccional amplía su campo de acción acerca de la conducta moral con el estudio de las "maniobras de poder" que fue motivo de un interesante estudio con alcance psico-sociológico por parte de Claude Steiner (2009). Los "juegos psicológicos" (Comunicación doble que sostiene conductas simbióticas) se realizan en la vía del sistema primario de referencia y las "maniobras de poder" se realizan por medio del sistema secundario de referencia.

La "conducta malvada" está presente en toda acción manipuladora que se realiza conscientemente. Si el correlato de la patología es el "juego psicológico", la maldad tendrá su correspondiente conducta en toda "maniobra" (juegos de poder con premeditación). Desde una perspectiva cristiana, mentira es lo contrario a Dios (Juan 14: 6). Con el término "mentira" no me refiero al hecho de "restringir la información" propia en defensa de nuestra autoestima y autoconservación. Me refiero a toda construcción ficticia del otro por medio de acciones difamatorias. Aquí, mentir no solo es decir algo que no es cierto, también es omitir algo cierto que debe decirse en aras de favorecer a determinado grupo político. En otras palabras, el control de libre expresión en los "medios de comunicación" individual y masiva necesariamente atenta contra la verdad. Presenciamos "libertinaje de expresión" cuando se omite la opinión del que piensa diferente o también de quien es diferente (racismo en el caso de la televisión y la publicidad), cuando informamos a medias o hacemos del periodismo una apología a los candidatos políticos que convienen al medio de 
información. El libertinaje de expresión también tiene que ver con la poca responsabilidad de quienes graban bromas sobre personas en situaciones diversas para ver cómo reaccionan ante el dinero, el sexo, la violencia, el terror, la falta de respeto y el sinsentido.

\section{La terapia neoadleriana como invitación a la autonomía dentro de la vida de fe en Dios}

El Análisis Transaccional es una teoría integrativa que se ubica dentro de la tradición psicodinámica (en la línea de Freud - Adler) y que goza de simpatía dentro del ámbito de psicólogos humanistas que lo incluyen dentro de su movimiento. Sin embargo, con sabiduría, ni Helmut Quitmann (1989) ni Helga Auer (1990), renombrados divulgadores de la "Psicología Humanística" incluyen la terapia de Berne como parte del cuerpo de la $\mathrm{PH}$ por tratarse de una orientación "... inequívocamente hacia la psicología profunda" (Auer, 1997 p. 59). Por otra parte, en el enfoque "cognitivo-conductual" se diseña un novedoso modelo de cambio, teorizando en parte, acerca de lo que Eric Berne denominó "mandatos frenadores" del "argumento de vida inconsciente" pero con recursos terapéuticos y revestimiento terminológico diferente. Es el caso de Jeffrey Young y su concepción de "esquemas desadaptativos", "patrones de vida autodestructivos" o "trampas vitales" (Young y otros, 2001 y 2013).

Quizá la proximidad a modelos que afirman lo personal y autonómico del individuo, se deba a que el sistema terapéutico de Berne está centrado en una "re-decisión" del plan de vida que suple los efectos nocivos del argumento inconsciente. $\mathrm{El}$ creador del "análisis conciliatorio" como lo llamó inicialmente, estaba identificado con autores de la filosofía existencialista, que afirma por encima de todo la libertad individual. El Análisis Transaccional tiene lenguajes de cambio potentes para acompañar dentro del camino de fe en la medida que atiende principalmente a reforzar autonomía en el sujeto. Por tanto, el análisis transaccional no favorece el sometimiento ni la adaptación a ideologías político-religiosas fundamentalistas que minan una sana vida espiritual en sentido religioso. Por línea semejante opera el teleoanálisis adleriano cuando no rigidiza la terapia en el sentido del sistema secundario de referencia que está centrado en el deber. Por eso, en este enfoque de terapia neoadleriana se tiene en cuenta pero se evita la "clasificación psicopatologista" propia de la psiquiatría, no se sobrevalora el poder de la hipnosis o de otras técnicas en las cuales no se ejercita la autonomía de pensamiento; en cambio, sí se dedica a reforzar el estado del yo Adulto y la disponibilidad al diálogo "yo estoy bien y tú estás bien" $(+/+)$ sin necesidad de recurrir a retóricas elegantes o terminologías solo accesibles a un grupo de privilegiados que comparten un lenguaje que la mayoría desconoce (Nada más lejano al estilo de Jesús que habla con parábolas $y$ que no se queda ni distante ni indiferente ante la gente, por lo general humilde, que se le acercaba para encontrar alivio). La terapia transaccional consiste, esencialmente, en optimizar la autonomía conductual del sujeto.

Conviene reconocer, a la luz del análisis transaccional, cómo la vida cristiana puede quedar obstaculizada por mandatos inconscientes autodestructivos asociados a las figuras significativas descalificadoras de su autonomía (perseguidoras o sobreprotectoras). El patrón de conducta imperativa inconsciente puede condicionar la experiencia religiosa que reencuentra al individuo con la figura de "Dios Padre" (heteronomía cristiana) que perdona y de una "Madre celestial" que lo acerca "al Hijo" (un hermano mayor divino que se presenta comestible). El niño teje la religión que aprende en familia junto a otros gestos de fe con su propia experiencia de Dios, aquella que sofisticará con el paso del tiempo. Esta idea podría ser objetada por quien quiere ver en estos términos una estructura de familia patriarcal impuesta. Sin embargo resulta más potente para un niño la imagen protectora de sus figuras significativas (madre y padre) cuando recibe permiso para vivir y aliento para hacerlo con disfrute (emociones auténticas) sin creerse más ni menos que los demás. La imagen paterna no tiene que ser superior ni inferior a la materna. La interpretación del niño depende de la capacidad de las figuras significativas a la hora de proteger (sin descalificar ni sobreproteger) su mundo emocional. 
El niño va ensayando sus aprendizajes tempranos de supervivencia, no solo ante el profesor en clase, sino ante toda figura que representa autoridad. La religión no se queda al margen. El catequista y el sacerdote pueden ser blanco de estos ensayos del niño que ya desde muy temprano aprendió a construir su propia situación de "inferioridad sana" (es pequeño y todavía dependiente como "Niño Libre") y "patológica" (como "Niño Adaptado" fútil, depresivo o paranoide). En el escenario creyente, Dios suele presentarse dentro del imaginario del niño como un personaje fantástico que puede resolver todos sus problemas, y, de no ser así, se le dirá que "por algo será". El niño entonces seguirá confiando en Dios porque hasta sus padres, a quienes considera "perfectos", le temen y le rezan, aunque sea se persignan o lo nombran cuando están en peligro. El niño todavía depende (hasta entrada la pubertad) de su concepción acerca de lo bueno que es Dios y la idea de "yo mismo" como "bueno" (autoconcepto). La Posición Existencial que se forma desde los primeros años de vida influye en la autoestima y en la idea de sí mismo del adolescente a través del juicio de las personas importantes que le autorizan o no a entenderse como "bueno".

El modo en que el creyente se relaciona con Dios está fuertemente influido por aprendizajes tempranos de supervivencia psicológica, y la zona patológica de nuestro aprendizaje puede minar la experiencia de tristeza y miedo por haber ofendido a Dios, y esta experiencia se concretiza junto al sentimiento de "vergüenza" (para el psicólogo transaccional se tratará del "rebusque de miedo") y arrepentimiento ante la figura paterna asociada con el Dios que perdona. También servirá que el sacerdote sea consciente de su propia capacidad de protección ante una persona que necesita ser debidamente protegida (no sobreprotegida) en su emoción auténtica (por ejemplo, tristeza dentro del arrepentimiento) y aconsejada. Durante el acto de confesión sacramental, el penitente puede dar cuenta no solo de pecados sino también de estrategias inconscientes de poder que el sacerdote puede reconocer para lograr mayor eficacia en su comunicación.

\section{El terapeuta neoadleriano y el sacerdote como figuras potentes de cambio}

El análisis transaccional ofrece herramientas de cambio donde el terapeuta es modelo de autonomía y logra ser eficaz en su propósito porque opera distinto que las figuras significativas, quienes influyeron crítica o persecutoriamente para que el paciente permanezca en estado de sistemática dependencia física y afectiva con ellos. El terapeuta teleoanalítico conoce técnicas paradójicas que procuran la complementariedad de los sistemas de referencia primarios y secundarios (Titze, 1983). Por ejemplo, he observado que en una sola sesión es posible obtener resultados altamente favorables cuando el terapeuta se alía al "sistema primario" hedonista del paciente obteniendo de él súbita respuesta de autoaceptación a pesar de las conductas "desagradables", "incorrectas" o incluso "perversas" que normalmente le generan emociones sustitutas y que el sentido común desaprueba de inmediato sin percatarse del esfuerzo inteligente del paciente por enfrentar su situación. La persona comprometida con la fe religiosa puede tener mayores posibilidades de vencer fobias, deseos y emociones que obstaculizan su aproximación a la vida de fe. Cuandolasituaciónloamerita, elpsicoterapeuta puede conectar con el asesoramiento espiritual y entonces la vida cristiana puede contar con el recurso de las técnicas de cambio conductual que sean necesarias.

La influencia de una adecuada comprensión de la vida religiosa puede ser saludable $e$ incluso terapéutica. El sacerdote es fácilmente identificado como "figura significativa" potente y sugestiva, de modo similar a cuando estamos en presencia del médico. La experiencia de aquello que el creyente denomina "gracia divina", al margen de tratarse de sugestión o acción de poderes sobrenaturales, puede ejercer cambios significativos de conducta que incluso con técnicas persuasivas de terapia no se obtienen. Me pregunto ¿Por qué un psicoanalista puede obtener los mismos cambios de conducta que un terapeuta de constelaciones familiares? Las teorías pueden ser divergentes, más o menos convincentes, 
pero la personalidad de los terapeutas puede ser muy congruente. ¿Es un terapeuta potente, protector, informado, prudente? El sacerdote, por camino semejante en la reflexión, la oración, la vida contemplativa y, sobre todo, la vida ejemplar, puede lograr elevado influjo de cambio, además de la sugestión que aporta su autoridad.

Es común que el sacerdote novel esté preocupado por conocer las posibilidades de su ayuda. Los fieles se encomiendan a sus oraciones y él no solo tiene información teológica sino además formación cristiana, y Cristo obraba milagros de sanación. Sin embargo, la experiencia cotidiana de asesoría espiritual y de confesión le persuade que es común la vida de pecado y que el cambio no se logra necesariamente pronto. En la perspectiva del conocimiento místico-religioso se valora la situación desde otro ángulo. Hay factores sobrenaturales de consideración. A pesar de los aportes acerca de psicología de la religión y de la psicología moral, Dios resulta una experiencia única para cada persona. Cambia el escenario de actuación terapéutica del "cura". El sacerdote, con todos sus recursos de ayuda solo aporta, por intentar un aproximado, el $10 \%$ del poder influyente en el cambio. La tentación de "solucionar" el problema moral del asesorado depende en elevado porcentaje a la acción divina y de la sinceridad del asesorado consigo mismo. Mirado el fenómeno moral desde la perspectiva cristiana, hay otras fuerzas de por medio donde la técnica psicológico-psiquiátrica se torna estéril. Hay "sectores del alma" en donde solo puede "ingresar" la gracia santificante y en donde la psicología simplemente calla. A la luz de la fe religiosa, la actuación del clérigo no influye en lo más significativo del cambio sino la misma acción del Espíritu Santo.

Sin embargo, este aproximado $10 \%$ de ayuda puede ser de importancia visto a la luz del conocimiento científico y del sentido común. La gente recurre al sacerdote por ser autoridad espiritual que ha recibido el orden sagrado. Además, le es posible ser facilitador de cambio conductual cuando realiza asesoría espiritual. El individuo que busca ayuda queda expuesto ante sí mismo, ante Dios y ante el sacerdote. El penitente busca retomar la única relación importante quebrada por su ofensa a los demás. Para el cristiano católico, el sacramento de la reconciliación no solo implica el "encuentro religioso" sino también un "encuentro terapéutico": el sujeto en confesión también se "desahoga", expresa su emoción al receptor que vive con él un "misterio sanador" en favor de su alma. Este hecho, que puede resultar poco serio para el observador racionalista, tiene significado terapéutico de mucho valor por su carácter lúdico. $\mathrm{El}$ sujeto que se confiesa al sacerdote entra en contacto, por analogía (inconsciente), con su figura importante de referencia que ahora escucha lo que normalmente "no se debe" mencionar en público: cosas "incorrectas" $e$ incluso socialmente "inaceptables" del sistema primario de referencia.

El "sujeto revestido" (el sacerdote) al que tradicionalmente se le dice "cura" o "padre" representa a Cristo, una figura que para él es poderosa y sanadora pero, al mismo tiempo, "mágica" porque hace de "médium" o intermediario en ese proceso "fantástico" (sacro) en el cual, diciendo el pecado con arrepentimiento uno queda libre de culpa tanto como de la acción maléfica del "diablo" (un ser que se representa en nuestro imaginario con piel roja y con rasgos animalescos que simbolizan su situación degradada dentro del mundo angélico). En el contexto cristiano-católico, la absolución a su vez restablece la amistad con Dios y deja apto al creyente para ingresar al cielo en caso de muerte; todo el beneficio ocurre "como si" el arrepentido no hubiera hecho ninguna cosa "mala" o "incorrecta" anteriormente. El personaje revestido hace una breve oración y con el símbolo de la cruz absuelve de toda ofensa a Dios (limpia de toda "mancha"). Visto en un sentido aun limitado pero eficaz, la confesión "purifica".

Desde la óptica teleoanalítica, puede haber una de alianza por parte del confesor con el "sistema de referencia primario" (hedonista y amoral) del penitente $y$, al mismo tiempo, este representa la norma del "sistema secundario de referencia". Con ello, estamos diciendo que el sacerdote, durante el sacramento de la confesión, está representando de modo 
singular a una figura arquetípica de salud mental precisamente por lo que tiene de lúdico y catártico el acto de escuchar lo que no es posible aceptar socialmente y mediar con gestos el perdón divino.

\section{Sentimiento de culpa y sentido de culpa}

Es necesario aclarar los términos "sentimiento de culpa" y "sentido de culpa". El "sentimiento de culpa" es un "rebusque" (emoción sustituta de una real), que implica acusación y reproche persistente que puede ingresar en el campo de lo "patológico" cuando no hay suficiente capacidad de "autonomía" y "autoprotección" (Junchaya, 1985) ni adecuado "autoconcepto" (Ellis, 1990). La culpa patológica entendida como "sentimiento de culpa" es reconocible por la actitud de autocastigo del sujeto con fuertes "sentimientos de minusvalía" (Adler, 1970). En el análisis transaccional se reconoce con claridad que el sujeto con "sentimiento de culpa" ingresa en un circuito de juegos de poder (Rol de Víctima) para sostener su "simbiosis" (dependencia física y psicológica), juegos en los cuales la propia inferioridad se refuerza en tanto se es "disculpado" de modo reiterativo. El objetivo del juego psicológico, en este caso, es asemejarse de modo no consciente a quien no se da cuenta de lo evidente (juego de "idiota") para evitar real compromiso de cambio. De modo semejante un sujeto puede obtener ganancia de "caricias" (reconocimiento) siempre que esté en situación de quien comete errores (juego de "patéame") atrayendo así personas con patología paranoide que lo puedan "patear" simbólicamente por medio de la crítica a su conducta "inadecuada" y "reprensible".

El sentimiento de culpa también puede estar asociado a la vergüenza. Para el análisis transaccional, la vergüenza puede ser sustituto afectivo del "miedo" (emoción auténtica) y en el Teleoanálisis tal emoción, al margen de ser "rebusque" o "el extrañamiento de quedar expuesto y ser mirado (...) con desaprobación..." (Erikson, citado por León y Zambrano, 2000 p. 37), es una experiencia innecesaria cuando afecta el progreso de una vida con los demás. No es gratuito que Erikson describa una oposición entre iniciativa y culpa. El sentimiento de culpa estanca; el sentido de culpa, en cambio, libera porque es reflejo de un elevado coeficiente lúdico en la medida que se goza de confianza básica (de la que hablaremos al final) y autonomía. La descripción eriksoniana del desarrollo de la personalidad no solo amplía el panorama de la teoría psicoanalítica, también aclara conceptos de psicología individual adleriana que alude al "sentimiento de inferioridad" en camino hacia el "sentimiento comunitario".

Para un cristiano, el "sentido de culpa", a diferencia del "sentimiento de culpa", permite al sujeto establecer, diálogos internos protectores que ante la conciencia de haber hecho inadecuado uso de la libertad no se siente "manchado" o "desmerecedor de amor" sino que experimenta la confianza de su propio Padre Nutritivo que está hecho a semejanza de un "Dios Padre" siempre dispuesto a perdonarlo (per = continuar + donare $=$ regalar) y ayudarlo a cambiar de ruta. En el "sentimiento auténtico del propio valor" (Lersch, 1974) del penitente se experimenta permiso para sentir tristeza por haber ofendido a Dios, y es de mucho aporte la actitud del sacerdote que, atento al uso de términos y actitudes del arrepentido, lo acoja protectoramente y lo invite de modo potente (Padre), al cambio de conducta, con previa actitud de escucha (Adulto), intuición y empatía (Niño) para conocer la situación particular del penitente.

\section{El sacramento de la penitencia y el secreto de confesión}

Tomando como referencia el texto de Royo Marín (1996), para el católico la confesión recibe también el nombre de "sacramento de penitencia" o de "reconciliación". Se trata de poner de manifiesto cuanto haya ofendido a Dios con sus pensamientos, actos y omisiones. El magisterio de la Iglesia da por sentada que es disposición divina (Mateo, 18: 18) realizar la confesión de las faltas ante un sacerdote tal como se declara en el concilio de Trento. El magisterio enseña que todo pecado involuntariamente omitido (por ejemplo, un olvido) durante una confesión debe declararse en la confesión siguiente. Cuando haya impedimento físico para verbalizar (gravedad 
que imposibilite vocalizar, cuando el sacerdote no comprende el idioma del penitente, vergüenza por exceso de escrúpulo, mudez, si se pusiera en peligro la fama del penitente por motivos ajenos a la confesión, etc.) basta con la intención de decirlo expresada de cualquier otro modo posible. No excusa de la integridad la gran afluencia de penitentes. Se recomienda también confesar los pecados veniales. La confesión debe ser expresa y en forma oral, solo en caso de impedimento se puede recurrir a signos y considerar el apoyo de un intérprete. No está permitido realizar la confesión por carta o por medio de un tercero (mensajero) ni recibir la absolución por esta vía.

La satisfacción del pecado corresponde a la "penitencia" que es la oración, el ayuno y la limosna, que sujetan y ponen freno a un nuevo intento de ofender a Dios. Tales indicaciones pueden cumplirse después de recibida la absolución o después de recibir la eucaristía. Se trata de una "penitencia sacramental" como gesto de reparación de la falta cometida que recibe su valor por los méritos de Cristo y del mismo penitente que son considerados también un "acto de culto". Aunque el sacerdote esté en pecado grave, tiene la facultad para absolver siempre que tenga la intención de hacerlo. El sacerdote está obligado a guardar el secreto de todo lo confesado tanto como la identidad de la persona con la cual cometió la falta, aunque peligre su propia vida. Si rompe el secreto de modo consciente será merecedor de excomunión.

El psicoterapeuta y el sacerdote confesor tienen por delante el imperativo de salvaguardar el derecho de cada persona a tener una vida propia, por eso la necesidad de conocer los límites del "secreto", que es cualquier cosa que debe mantenerse oculta.

Secreto natural: es obligatoria la reserva cuando uno se entera por casualidad, mientras uno investiga o por confidencia inesperada.

Secreto prometido: se promete discreción después de recibir la confidencia.

Secreto pactado: se pacta tener discreción antes de recibir la confidencia.
Secreto de asesoría espiritual, religiosa o moral: es un secreto cuasi-sacramental. En ningún caso se puede revelar.

El profesional, abogado, médico, psicólogo, etc. trabajan en función de códigos de ética que les exige tener cuidado respecto a su comportamiento y al debido trato de la información recibida por parte de las personas que les confían su vida privada. Al sacerdote, que debería ser modelo de conducta ética, también le corresponde velar por el secreto de confesión que, en más de una ocasión, he visto vulnerado.

Un ejemplo significativo para nuestro tema: alguien pasócercadel confesionarioy refiereque escuchó involuntariamente (secreto natural) un pecado confesado al sacerdote. Ocurre a veces que no se respeta el "espacio confesional" de los "penitentes". Con frecuencia, ellos esperan su turno a poca distancia del lugar de confesión. Esta incómoda situación no es común cuando se trata de una confesión dentro del despacho parroquial donde el sacramento suele realizarse a puertas cerradas. Existen otros comportamientos alrededor de la invasión del "espacio confesional" que no se suelen contemplar y que pueden afectar el "espacio psicológico" requerido para una adecuada confesión. Es frecuente que algunos miembros de la fila de espera revisen su celular o conversen con otras amistades a quienes, no pocas veces, les han "reservado el sitio". Tal conducta es inadecuada dentro de la "Zona de Dios" que es el templo y todo lugar cercano al sagrario y a la meditación espiritual (idea semejante en Éxodo 3: 5).

Otro ejemplo de cómo se vulnera el derecho a la intimidad es el caso de sacerdotes (en un templo extranjero) que ventilan alegremente, durante el almuerzo, partes de la confesión de un penitente que solía confesarse en su jurisdicción y cuya identidad podría ser fácilmente reconocida por los comensales (secreto moral).

Una ocasión representante de muchas es aquella en la cual el sacerdote tiene hipoacusia y solicita la confesión "en voz más alta" o, simplemente, el local para confesar incluye 
la interrupción de personas que circulan por el sector y, por más que adopten una actitud sigilosa, podrían afectar con su cercanía la disposición de continuar el sacramento.

Tengo conocimiento de lugares en donde el confesor ha elevado la voz haciendo audible sus comentarios acerca del acto confesado. En una ocasión el sacerdote (en el templo de una comunidad elitista cuyos miembros fundadores fueron acusados de actos contrarios a la vida cristiana) al no escuchar nítidamente una confesión "en voz baja", empezó a decir notoriamente exaltado y "en voz alta", un pecado que el penitente nos informa "no haber cometido" (difamación), motivo de escándalo por parte de los penitentes que esperaban su turno. Es lamentable que para algunos sacerdotes no se haya entendido la importancia que tiene para Cristo perdonar sinceramente (Lucas 15: 11-32). Tengo conocimiento de sacerdotes confesores de vida ejemplar. Mi percepción (no libre de sesgo) sobre la comunidad cristiana me invita a reflexionar críticamente sobre ella porque creo en la capacidad de superación de quien se autodenomina "seguidor de Cristo" y miembro de una asamblea "católica" (= universal). No sé cuál es la experiencia de innumerables católicos al respecto. Aunque sí conozco personas que, por trato semejante o más grave de lo que he relatado, han dejado definitivamente de participar en la vida sacramental por causa de este tipo de maltratos.

El Papa Francisco, desde el inicio de su pontificado, hasta donde observo, está haciendo notables esfuerzos para que la situación de la Iglesia cambie en favor de un regreso a la vida según el evangelio. Está dando muestras de sencillez y desprendimiento de lo accesorio en el Vaticano, y no sólo como "un gusto" o "preferencia personal" que "haya que aceptar" en Roma, como preferirían algunos, sino de un "estilo de vida modélico" para todo cristiano que quiere "seguir a Jesús" (Marcos 6: 8) y que tiene disposición de servicio (Lucas: 22: 27). Según he comprendido del mensaje cristiano-católico, Cristo envía a sus sacerdotes, no solo para absolver pecados en el nombre de Dios, sino que pide aún más cuando se pone de ejemplo: "Yo soy el buen pastor. El buen pastor da la vida por las ovejas" (Juan 10: 11). El Dios cristiano no quiere seguidores tibios (Apocalipsis 3: 16), ni diplomáticos (Marcos 11: 15-18), ni individualistas (Mateo 5: 21-24) sino de aquellos que están dispuestos a vivir la familiaridad con Dios (Marcos 3: 35). Poner atención sincera al evangelio de Cristo será, a mi entender, la mejor "terapia" que requiere la Iglesia. Antes de evangelizar a los "paganos" es necesario el retorno a la verdadera alegría cristiana, por ejemplo, la de saber que un hermano desea volver a casa (Lucas 15: 1-10).

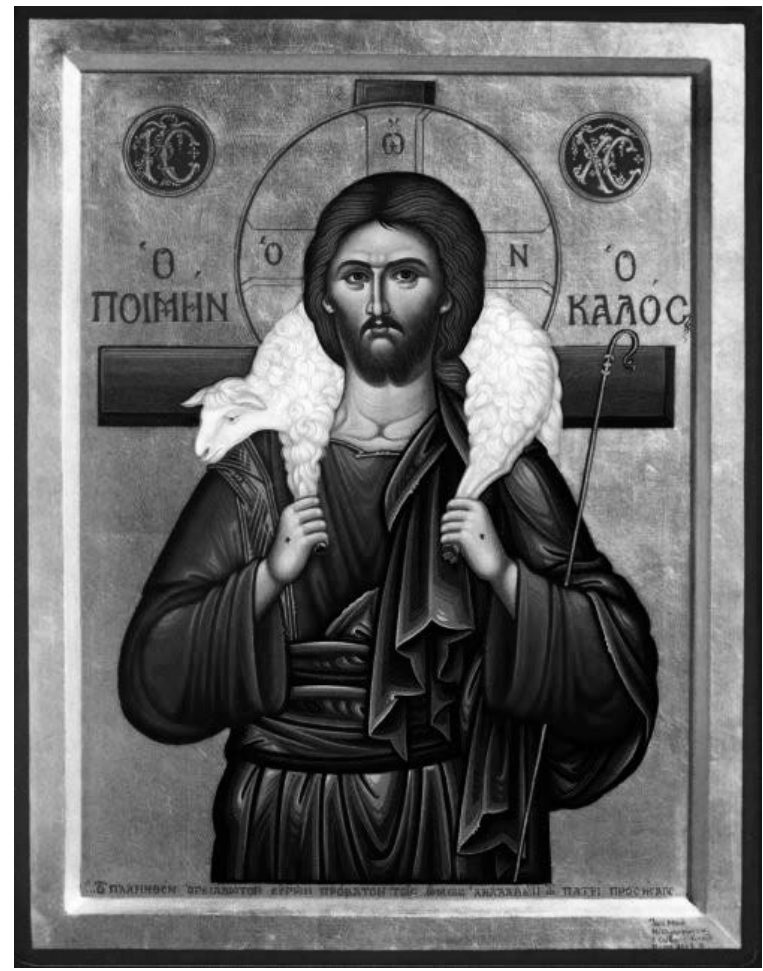

El Buen Pastor

\section{Pecado y perfección cristiana}

Para el cristiano-católico, pecado es pensar, sentir y actuar en contra de Yahvé, un Dios que se presenta comunitario y trino, lo cual significa actuar sin caridad con el prójimo. La vida en religión (religare) vuelve a ligar con Dios y el camino a Dios pasa por la vida en fraternidad con los hombres. Incluso Cristo llega a decir que sus seguidores serán reconocidos, sobre todo, porque se aman entre ellos (Juan 13: 15). El pecado fundamental contra Dios es el que se realiza contra el Espíritu Santo, otro miembro de la misteriosa comunidad divina. 
Pero lo inaccesible a la comprensión de este Dios supra-racional se torna asequible en el otro, el forastero que pone su tienda de campaña en medio de nosotros, Jesús el Hijo del carpintero José que amaba a una joven llamada María de Nazaret.

Dios religa al creyente con él cuando este acoge al que es diferente, al que viene de otra cultura y creyendo en cosas distintas. El Dios cristiano incluso exige "perfección" en el amor al enemigo (Mateo 5: 44). Cristo no trató amablemente a Judas cuando este lo traicionó por dinero, mas no actuó en su contra teniendo el poder para hacerlo. Fue el mismo Judas quien desesperó ante su propia conciencia. Amar al enemigo no significa permitir que este obre injusticia y tratarlo con afecto sobreprotector. Amar al enemigo es, en principio, tomar distancia razonable sin tomar venganza (Mateo 10: 16). Amar perfectamente, seguir amando, no significa consentir el acto malintencionado. Por el contrario, es disponibilidad a poner al enemigo en manos de Dios (perdonarlo) y perdonar de modo manifiesto a quien muestra arrepentimiento sin juegos de poder.

El cristianismo no se resume como una serie de recursos cuasi mágicos para que un individuo se vaya al cielo. Estar libres de pecado significa ampliar el coeficiente personal para dar testimonio de Jesús, y, antes que un Jesús milagroso y resucitado, se trata de un Jesús cercano. Se da testimonio de Cristo en la capacidad para cenar con los rechazados y con aquellos que tienen menos poder e influencia. No se trata de discriminar al rico sino de dar más cariño, salud y alimento a quien no lo posee. No se trata de salvar "el propio pellejo" afirmando nuestra castidad física para "ser puros" (religión sin los demás) sino afirmar la amistad y el respeto mutuo, permitiendo que los demás, sobre todo los pobres, vivan lo que Dios ha creado para ellos también en esta vida. Si no es así, el cristiano distorsiona la fe y la reduce a "reglas de obediencia", a una religión "convenida" (para no ir al purgatorio o al infierno) e "hipócrita" (contraria al evangelio) para un grupo de selectos (segregacionista y por eso anticatólica) que tienen asegurado su futuro eterno. Un cristiano individualista no dista de vivir como lo hacían los saduceos.
Cristo tuvo momentos importantes de soledad pero su "evangelio" (buena noticia) era el reinado del amor. La perfección cristiana consiste dejarse amar por Dios que se hizo hombre sencillo entre los hombres, aun a riesgo de ser humillado y asesinado por los grupos de poder político y religioso.

\section{Ansia de poder y mentira}

El pecado ahora se hace más problemático para quienes tienen poder político $y$ económico porque al ingresar Dios en la historia nos enseña que él no prefiere vivir como rey sino como pobre de padres pobres y no hace negocio con la salvación. Viene a perdonar cuantas veces sea necesario. El afán de lucro y la mala distribución de las riquezas alejan de Dios (Marcos 10: 25), lo mismo que el adulterio (Hebreos 13: 4). Al que abusa del poder y a quien trafica con su voluntad lo saca violentamente del templo con "grito ético" y empujón si fuese necesario (Marcos 11: 15-17). Cristo acoge a toda persona con verdadero deseo de cambio: el encuentro de Jesús con personas de otra confesión (Juan 4: 7-40), incluso con la prostituta (Lucas 7: 36-50) se realizan dentro de una atmósfera de amistad y compasión, respectivamente. $\mathrm{El}$ mensaje es claro, Cristo no vino a condenar sino a perdonar (Juan 2: 17). Durante su estadía en la Tierra, sin embargo, fue claro y enfático contra todo tipo de abuso de poder, ya sea por estatus e influencias (Mateo 20: 20-28), ya sea por violencia explícita (Lucas 22: 50-51), ya sea por moralismos $e$ inquisiciones (Juan 8: 3-11), tal como lo sería hoy con quienes abusan de su poder: demagogos, mentirosos, ladrones, racistas, "contaminadores del medio ambiente" (en esto somos corresponsables), secuestradores, violadores y pederastas (Lucas 17: 1-2).

La obsesión por el poder es propia de un espíritu que no solo anhela sobresalir sino de alguien que necesita ver a los demás en situación de inferioridad para sentirse cómodo y seguro. La persona guiada por esta súper-compensación de su oculto sentimiento de minusvalía tendrá actitudes de soberbia y altanería que son formas de ser relacionadas con la decisión básica propia de personas con disminuida 
protección psicológica. El ansioso por el poder sigue una meta ilusoria de seguridad que lo desliga del sentido comunitario. Aparece, por tanto, como un sujeto especialista en maniobras de dominio que solo se sostienen a través del autoengaño. El análisis transaccional (Junchaya, 1985 y Kertész, 2010) grafica estos patrones referenciales del yo en la "posición existencial" (P. E.), forma en la cual un sujeto se percibe a sí mismo, a los demás y al mundo. El Teleoanálisis adleriano asigna para este fenómeno los términos de "autoimagen", "heteroimagen" y "cosmoimagen" y reserva un término aportativo para la "psicología del autoengaño" como es el de "apercepción tendenciosa", en donde el neurótico finalmente encuentra todo aquello de lo que rehúye y aprecia el mundo desde la óptica de sus intereses inconscientes (Titze, 1983). Un concepto semejante es "pseudopercepción OK" de uso frecuente en el Análisis Transaccional cuando se refiere a la sensación de estar bien siempre que se encuentre la persona dentro de su impulsor de conductas No OK.

Sabemos acerca del derecho a la intimidad y al secreto pero también advertimos las consecuencias de la mentira, que es decir lo contrario a la verdad con la intención de perjudicar a un semejante. Esto es distinto a un tipo de "engaño" o mejor, "restricción de la información" que no dice lo cierto con la finalidad de proteger la propia autoestima, la integridad individual o porque simplemente no tiene el deber de mostrar la propia intimidad. Al contrario, la mentira adquiere rasgos psicopáticos porque tiene la intención de hacer daño y con ello obtener una pseudoventaja. Las relaciones humanas están tejidas necesariamente de restricciones y engaños que el lenguaje del sentido común denomina "mentiritas" o "mentiras blancas". Ser "directos" y "veraces" todo el tiempo es la persecución, por lo general bien intencionada, de un fantasma de sinceridad que se desea proyectar hacia los demás por ser motivo de reconocimiento social. Pretender "ser directos" es ya una máscara autoimpuesta. El cristianismo condena la mentira, el engaño malintencionado y no la restricción de la información. La persona escrupulosa no reconoce con facilidad la línea divisoria entre una y otra. Encontrar error en todo es tan inauténtico como pretender no ver ningún defecto en nada.

Pienso que el pecado encuentra sus orígenes en la mentira, cuya estructura se asemeja al bien que representa la restricción de la información. La maldad es potente y eficaz en el mundo porque no es rápidamente detectable en su origen. La mentira y las maniobras de poder están íntimamente ligadas y constituyen el núcleo de toda acción mala. Dios es "comunidad" (trinidad) y el mal se grafica como "legión" (Marcos 5: 9) algo disperso, de andar sinuoso y de lengua bífida, como en la serpiente que se asocia con el diablo. El ansia de poder es producto de una distorsión del sentido del otro, un poder que se ha descontextualizado y opera al margen de las "reglas de juego": hace trampa. No es de extrañar que toda maniobra de control de la voluntad ajena sea descrita como el inicio del mal:

$\mathrm{Si}$, según Nietzsche, el deseo de poderío tiende a la "visión de los sojuzgados", a la conciencia de poder disponer y al triunfo de la superioridad, en ninguna parte encontrará mayor satisfacción que a la vista de la miseria y sufrimientos que proporciona a los demás. Estas son las circunstancias que permiten explicar la maldad y la crueldad y que hacen comprender que el poder se haya siempre considerado como algo malo. En todo caso, la maldad es una derivación del deseo de poder (Lersch, 1974 p. 133).

Será necesario conocer los "mecanismos de defensa" (Freud), la sobrecompensación de los sentimientos de inferioridad (Adler) y las maniobras de poder (Steiner) para ir captando el momento en que estamos ante un problema psicológico o ante actos malintencionados. $\mathrm{El}$ análisis transaccional tiene en los "juegos psicológicos" (Berne, 1975) una herramienta valiosa para reconocer la comunicación implícita que fomenta el control casi hipnótico de la conducta de otro y que sirve para reforzar conductas dependientes en el adulto. El teleoanálisis adleriano da cuenta de la diferencia entre sujetos que hacen efectivo 
su poder en sociedad dentro del "complejo medios-fin activo-agresivo" y gente propensa a mantener relaciones poder no socializado en el "complejo medios-fin pasivo regresivo" (Titze, 1983). Las conductas aparentemente sumisas y de victimismo encierran peligros de interacción difíciles de captar si se desconoce cómo la manipulación se complementa inconscientemente con apoyo de terceros mediante roles dramáticos de "Salvador", "Perseguidor" y "Víctima" (Edwards, 2011).

Desde una perspectiva moral (religiosa), la mentira es madre de otros pecados como utilizar estrategias sexuales para controlar la conducta de una persona. En este caso, el problema no señala directamente la relación sexual como pecado sino a la acción abusiva en tanto descalifica la libertad del otro y le antepone el sexo como carnada para el logro, por ejemplo, de una relación matrimonial convenida a cambio de cualquier beneficio psicológico o material. El sexo se convierte así en una herramienta de poder omnipresente en la publicidad y en programas de televisión en donde, además, se suma otra forma antigua de descalificación del otro en el "racismo" y el "sexismo". La segregación racial y sexual es un problema ético ante el cual los creyentes no suelen protestar más que a puerta cerrada. También la sexualidad desbocada puede crear víctimas reales como las derivadas de la pornografía en donde se explota a personas económicamente y se las induce a exponer su salud física y psicológica.

También es una hija de la mentira la sutileza de sobredimensionar el valor de acciones moralmente indebidas que pueden desviar la atención de otros pecados de implicancia evangélica nuclear. Por ejemplo, centrar casi obsesivamente la atención en el pecado sexual pero hacer de la vista gorda ante el racismo, el clasismo, la explotación laboral y el autoritarismo político y religioso. La atención del moralista también puede distribuirse en lo antedicho y en problemas que atentan contra la mayoría de latinoamericanos, como por ejemplo la injusticia social. Con ello no estoy hablando necesariamente de una ideología política ni de un solo tipo de enfoque en teología sino de hacer patente la opción preferencial de la Iglesia católica por los más pobres, por aquellos que no tienen poder de respuesta ante el abuso de quienes, en tanto abusadores, detentan el poder.

Dirá el empresario "cristiano-racista" que mejor pongamos en la publicidad gente de raza afroamericana u oriental pero no andina. Se acepta sancionar a los ladrones que roban por las calles pero es más difícil cuestionar el hecho de que en varios distritos "exclusivos" de Lima se permita no poner veredas para quienes no pueden ir en auto. Todo abuso de poder se sostiene en la mentira y en su hijastra "la cortina de humo". Es fácil sostener la mentira cuando se tiene mucho dinero y "contactos". La puerta para el gran pecado (soberbia) es el ansia de lucro y de notoriedad. Tenemos entonces las cuatro "p" de las que hizo mención un viejo sacerdote y confesor: "poder, placer, prestigio y plata". Los pecados "de la carne" conforman solo un sector de la vida anticristiana. En cada una de estas tendencias del yo carente de sentido comunitario late el autoengaño a modo de "apercepción tendenciosa" (Titze) en donde solo se ve aquello que sirve al propio interés, de tal forma que malhechores de verdad son "otros entre los demás". Siempre hay una justificación socialmente aceptable cuando se trata de uno mismo. He allí el núcleo del pecado como mentira: el autoengaño. Quizá darse cuenta sea demasiado doloroso. La psicoterapia puede servir para erradicar alguna de estas máscaras.

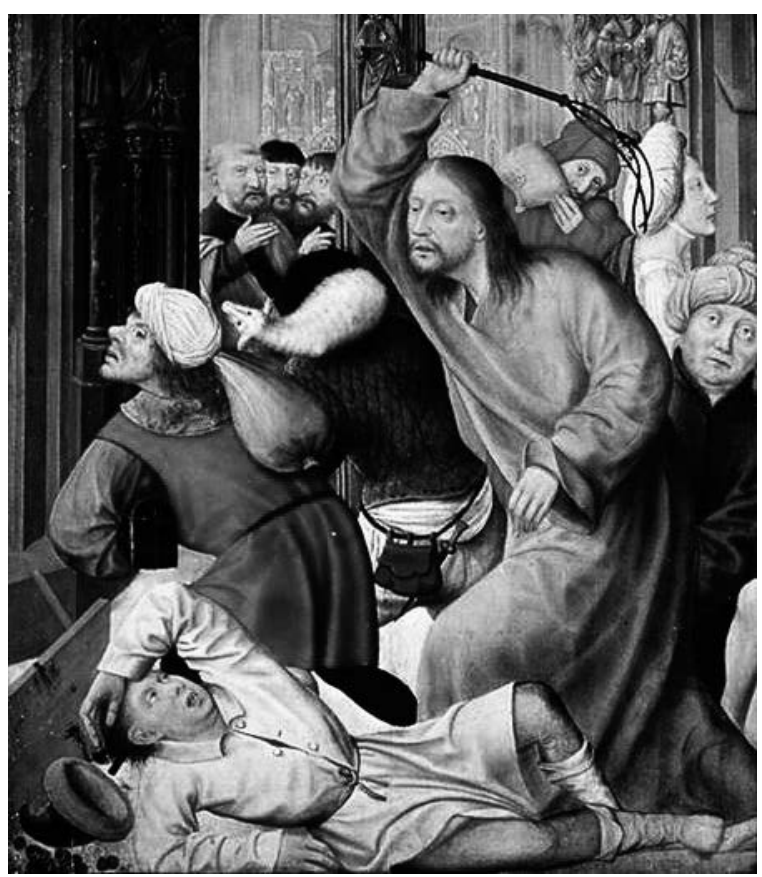

Cristo expulsa a los mercaderes del templo 


\section{El demonio, formas de ataque y seducción}

Para la teología cristiana, "el diablo" es uno de los nombres reservados a "Lucifer" (Latín: "Portador de luz") o "Satán" (Hebreo: "El adversario"). No se trata de alguien que siempre fue maligno por excelencia sino de un ser angélico, entidad con intelecto sobrehumano, que nuestra inteligencia no podría superar si no es con auxilio divino. Actualmente hay posiciones diferentes respecto a la creencia en el diablo. Una postura interesante es la que afirma que a él y a sus demonios no les conviene que el mundo crea en ellos. Solo así el diablo o Satanás podría cumplir con facilidad su actividad de engaño (Juan 8: 44). Sin embargo, hay teólogos que no creen en el demonio como entidad personal (Pikaza y Aya, 2009) sino como una personificación del mal producto de tradiciones religiosas foráneas que influyeron en el judaísmo. Para tentar, el enemigo no se presentaría como un ser repulsivo sino atractivo (2 Corintios 11: 14). Por ejemplo, mediante la atracción hacia un "cristianismo esquizofrénico" donde uno puede ser creyente por obras siendo realmente ateo en las intenciones del corazón (1 Corintios 13: 1-3).

El proceder típico del diablo es crear discordia por medio del exceso de placeres que promueven el abuso del cuerpo de personas con fines de lucro: prostitución, drogas $y$ pornografía, porque él es entendido como "dios de este mundo" (2 Corintios 4: 4). El enemigo del cristiano promueve fanatismo en cualquiera de sus formas como la inequidad para que haya injusticia social (Mateo 6: 24). Procura la confusión ideológica y tienta con un mismo tipo de pecado y al mismo tiempo a religiosos en todas partes del mundo de tal forma que diese la impresión de que se trata de un mal generalizado. El enemigo tentará sin descanso y con nuevas estrategias a los seguidores de Cristo (Lucas 22: 31). El fin es claro: derribar todo sistema que promueva la fe cristiana (católicos, protestantes, ortodoxos). Opera en grandes y pequeños grupos, logrando sugestionar a colectivos enteros. Por ejemplo, por medio de ideologías se acercaría a gente poderosa para incitarla a que realice actos contra la humanidad. De modo particular operaría según la debilidad o carencia física y psicológica de cada persona.

El cristiano está seguro con respecto a la acción diabólica porque cree contar con el auxilio de su Dios. El enemigo no puede tentar a una persona más allá de sus fuerzas (Job 1: 12), incluso en caso de "infestación" y "posesión" no puede arrebatar la vida. En el plano individual, el enemigo busca principalmente que el intelectual radicalice la incoherencia entre sus convicciones y de su propia vida. Del mismo modo, procura que el tentado quede confundido con multitud de ideas con apariencia de verdad:

Ustedes son de su padre el diablo y quieren cumplir los deseos de su padre. Este era homicida desde el principio y no se mantuvo en la verdad, porque no hay verdad en él; cuando dice la mentira, dice lo que le sale de dentro, porque es mentiroso y padre de la mentira (Juan 8: 44).

Cuando el individuo es creyente fiel está prevenido ante la tentación, por ello la sugestión puede tornarse más severa y directa. Para el creyente medio, el enemigo, como entidad personal, buscaría desorientar por medio de artificios. Inicialmente, merodea y luego, crearía insipidez en la oración. El diablo buscaría amedrentar, a quien se interese por acercarse a Dios, mediante el susto que corresponda. Para lograr su objetivo, el enemigo aprovechará circunstancias mediante las que puede desmoralizar según la debilidad de cada quien: Habladurías y traiciones si la persona suele dar mucha importancia a la opinión ajena; trastorno psicosomático severo, cuando la persona no sabe expresar emociones; egolatría y ansia de poder si la persona tiene cargo de autoridad o influencia.

Para gran sector del cristianismo, el diablo es conocido como un ángel que tiene inteligencia sobrehumana y por tanto es "imitador" $y$ "estratega" por excelencia (semejante al "Adulto en el Niño" del Análisis transaccional). Sabe cuál es el punto débil de la persona a la cual se aproxima. Le tienta en función de su parte más débil, física y psicológicamente, según su argumento de vida inconsciente. Si la 
debilidad psicológica está asociada a mandatos como no sientas, no pienses y no decidas, la persona tendrá dificultad para contactar con sus sentimientos y arriesgarse a cambiar y el diablo adoptará la forma de tentador mudo: "Eso no lo puedes haber hecho tú", "No cuentes tu pecado, pensarán mal de ti", "¿Eso es pecado?", "Que nadie sepa sobre aquello que te sucedió". La idea del tentador mudo, de paso daña el cuerpo. Callando se acumula energía de emociones no permitidas que degeneran en diversas enfermedades. No es gratuito que en el evangelio de Marcos, posiblemente el más antiguo de los evangelios sinópticos (Nueva Biblia de Jerusalén, 1998), lo primero que hace públicamente Cristo es curar a los enfermos. Los demonios que el Mesías cristiano expulsa pueden ser para la medicina científica enfermedades somáticas. Para el judío del siglo primero se trata con seguridad de "las fuerzas del mal" (demonios). El tentador mudo (Mateo 9: 32-34; 12: 22 y Lucas 11: 14-15) no solo debiera entenderse como aquel que no puede hablar por impedimento físico, lo mismo vale para quien no puede "ver" (su propia egopatía), "oír" (opiniones distintas) y "sentir" (emociones auténticas).

El ser humano ha llegado a ser lo que es gracias a la permanente reformulación de su instinto de conservación y este esfuerzo magnífico ha dado como resultado la inteligencia mediante la cual podemos construir la realidad junto a los demás. El natural egoísmo y el deseo de poder ha desembocado en "necesidad de estimación", punto central del encuentro social que nos permite afirmar nuestros egoísmos de modo no consciente. Sin embargo, una persona con profundo sentimiento de minusvalía percibirá el mundo de la estimación ajena como un objetivo de control absoluto y tenderá al ansia de notoriedad (Lersch, 1974). La mayoría de personas experimentan menoscabo de su autoestima dentro de una atmósfera sin Dios, en donde se rinde culto a los pequeños dioses (fama, status, notoriedad, atractivo físico) que representan valores dentro de la cultura. Incluso el intelecto puede ser un buen pretexto para llamar la atención cuando se sabe mucho de un tema y para obtener reconocimiento, incluso para hacer alarde de superioridad. El ansioso por la notoriedad vive sugestionado por una pseudo-percepción $(+/+)$ que le permite sobrevivir descalificando su propia mediocridad existencial. El histrionismo sin empatía se torna en una vida sedienta de espectáculo (introvertidamente) o en una vida espectacular (extrovertidamente) copiando ideas y modos de ser ajenos, haciéndose pasar por hombre exitoso, superior y confiable mientras "vende gato por liebre". Satán, el tentador espectacular, le decía a Cristo en el desierto: “... Si eres el Hijo de Dios, di a estas piedras que se conviertan en panes... (...). Si eres el Hijo de Dios, tírate abajo, porque está escrito: A sus ángeles te encomendará, y en sus manos te llevarán, para que no tropiece tu pie en piedra alguna" (Mateo 4: 3-6).

Detrás de las formas en que el enemigo se presenta hay una que figura recurrente. Se trata de un tentador religioso que reconoce el poder de Dios y le teme (Marcos 5: 6-7). El espíritu de la mentira usa los recursos que sean necesarios para confundir imitando voces y apariencias que tienen por único fin negar la redención. No solo imita la voz de conocidos y parientes fallecidos, también imita al experto en Biblia. Para tentar a Cristo recurre a la revelación y al argumento teológico. La astucia del enemigo se revela entonces en su habilidad para usar la Sagrada Escritura, de ahí que tengamos en cuenta al tentador teólogo que reta a Cristo: "Está escrito..." (Mateo 4: 4).

Visto a la luz del teleoanálisis adleriano, el diablo representa una personificación arquetípica de los intereses del "sistema primario de referencia" que visto sin el complemento del "sistema secundario de referencia" reúne los requisitos para hablar de aquello que contradice el orden apolíneo de la lógica del sentido común. El Satanás entonces "desvía" al sujeto del camino "correcto" y lo tienta para que obre según sus pasiones. Incluso el diablo es tenido por quien "sugestiona" (apercepción tendenciosa) y "embriaga" al hombre en su propio pecado. El diablo no puede representar la ligazón (religio) de los sistemas de referencia sino su ruptura: "Así como "symballein" significa unir, congregar, concentrar, encontrarse, "dia-ballein" (...), significa disgregar, dividir, separar" (Díaz Mateos, 1996 p. 118). La parcialización de cualquier sistema de referencia es ya una forma de 
"rigidez del constructo psíquico" (patología). Ocurre distinto con la figura del sacerdote que se reviste de lo sagrado, como veremos luego. Estas interpretaciones pueden servir al terapeuta para traducir el mundo creyente sin afirmar o negar su creencia. Para el psicólogo, es posible intuir la acción del "diablo" como entidad personal enemiga o como "la maldad" de una conducta conociendo la dinámica de las finalidades presentes en cada sistema referencial.

\section{La conversión religiosa}

La conversión a Cristo puede experimentarse como proceso gradual o como súbita respuesta. Para el cristiano Dios es Amor (1 Juan 4: 8) y él es quien toma la iniciativa en su aproximación al hombre (Génesis3:9; Jn3:16).Paraser "sanados" será necesario estar atentos a "Dios que pasa" (Marcos 5: 27-28). Puede ser que nunca más pase y el silencio podría ser la respuesta al juego permanente de quien abusa de su bondad. Dice entonces el culpable acompañado del sentido común (sistema secundario de referencia): "Un Dios infinitamente bueno no puede haber creado el castigo eterno. Tarde o temprano, el mismo sujeto de culpa dirá acompañado del deseo (sistema primario de referencia): "Puedo insistir en mi pecado". No hay respuesta más dolorosa que cuando Dios calla, pues ha llamado muchas veces y él no presiona, no fuerza las cosas porque conoce lo que realmente hay en el corazón del hombre (Jeremías 17: 10; Romanos 8: 27; y 1 Tesalonicenses 2: 4). Con Yahvé no se puede jugar doble porque sabe cuándo espera en vano (Lucas 16: 15 y Apocalipsis 2: 23). Para un cristiano lo más cercano al infierno es el silencio de Dios. Quizá Dios nunca más vuelva a insistir y será el mismo interesado quien deba tomar la iniciativa como intento de recuperar su amistad.

Para el creyente, Dios no está dentro de la lógica del mundo. Se espera que el humano por lo menos sea bueno para luego ir al cielo (1 Timoteo 2: 4). Sin embargo, es interesante que el Dios cristiano diga muy poco del cielo (1 Corintios 2: 9), y del infierno solo hable con severidad (Mateo 7: 22-23). En cambio, predica un "evangelio" (buena noticia) y de lo importante que el humano es para él (Mateo 10: 29-31). Como la persona que ama, no anda persiguiendo a su pareja pidiéndole cuentas sobre con quién estuvo durante el día. No está repitiendo sobre qué cosas le regalará si lo trata bien sino que, de diversa manera, con hechos y palabras, le expresa cuán importante es ella para él. El cristianismo se parece más a una relación de novios que a un juzgado en donde "todo lo que alguien diga irá en su contra" y menos se parece a relaciones tipo subasta "a ver, quién da más". Importa sí el temor de Dios. El temor es un sentimiento protector, propio de la seriedad (Lersch, 1974) y sirve para tener cuidado. "No cabe temor en el amor" (1 Juan 4: 18) ha de ser entendido en otro sentido: "En el amor no hay miedo". El miedo es una emoción paralizante que no deja pensar y por ello nos expone al fracaso, a lograr precisamente lo que no queremos. En español "temor" es controlable y positivo, porque ayuda a cuidar lo que tenemos, a mantenerlo. Para un cristiano, temer a Dios significa no contentarse con poco y no dejar pasar aquello que es "lo único importante".

¿Qué es convertirse a Dios? Hay una escena del Apocalipsis que sugiere una respuesta desde la visión creyente: "Cuando lo vi, caí a sus pies como muerto. Él puso su mano derecha sobre mí diciendo: "No temas, soy yo, el Primero y el Último, el que vive; estuve muerto, pero ahora estoy vivo por los siglos de los siglos, y tengo las llaves de la Muerte y del Abismo..."..." (Apocalipsis 1: 17-18). Juan describe con lenguaje propio de su tiempo la experiencia del cristiano ante su Dios-Amor cuya presencia es terrible y difícil de soportar. A la autoridad no se le sostiene la mirada por mucho tiempo, a la persona honorable se le mira con devoción, pero el cristiano que se atreve a mirar a Dios a la cara se encuentra ante la mirada de Cristo resucitado y lo natural será caer rendido, porque su mirada de amor es para el atrevido su propio juicio espiritual. El mejor de los cristianos será consecuente y dirá lo mismo que Pedro, el elegido: "Aléjate de mí, Señor, que soy un hombre pecador" (Lucas 5: 8). Algo similar harán los seres angélicos del apocalipsis: "Y todos los ángeles que estaban en pie alrededor del trono de los Ancianos y de los cuatro Vivientes, se postraron delante del trono, rostro en tierra, y adoraron a Dios..." (Apocalipsis 7: 11). Los seres más lúcidos del 
mundo espiritual solo tienen gratitud por haber recibido la existencia y toda su inteligencia queda como nada al lado de quien les ha regalado la vida. Ahora se puede entender mejor la respuesta cristiana de conversión: Convertirse a Dios es el atrevimiento de dar la cara a Dios y de mirarle a los ojos porque Yahvé es un Dios bueno y digno de confianza (Salmos 27: 8-14).

Dios ahora tiene rostro e historia personal entre los hombres por medio de Jesús de Nazaret. El cristiano puede mirar ya no la "zarza ardiente" (Éxodo 33: 20-23) sino que puede cruzar su historia con la de Cristo crucificado. Puede experimentar tristeza y dolor por haber traicionado al "más bueno de sus hermanos" (Cristo, Hijo de Dios-Padre), el único realmente bueno. Para que haya reconciliación es necesario reconocer que no se ha hecho bien. Se trata de una situación especial, de una injusticia, porque la persona con la cual quiere reconciliarse ha sido maltratada adrede y sin embargo no hay muestra de rechazo en su mirada. Cristo fue traicionado por Pedro y este al darse cuenta que había ofendido a Dios, tuvo la valentía de mirarle a los ojos. ¿Cómo habría sido la mirada de Cristo a Pedro? Lo que nos revela Lucas es que Pedro echó a llorar como un niño pues Cristo no era fingido y no podía disimular su ternura (Lucas 22: 6162). En cambio, Judas que también traicionó a Cristo se arrepintió pero no se atrevió a mirarlo y entonces actuó con desesperación (Mateo 27: 3-5). ¿Qué significa para un cristiano mirar a los ojos de Dios? Significa tener entera confianza en su perdón, por un lado y, el deseo de no volver a dejar la posibilidad de traicionar ni en la mente ni en el corazón al único que merece el nombre de "mejor amigo".

\section{La "confianza básica", experiencia de fe y "sentido del humor"}

Los primeros cristianos hacen suyo el dibujo de un pez (gr. Ichthys) acrónimo que significa "Jesucristo, Hijo de Dios, Salvador". El dibujo era usado como un símbolo por medio del cual se identificaban en secreto debido a que, durante las persecuciones romanas, podían ser asesinados. Naturalmente había miedo pero ellos estaban dispuestos a mantenerse fieles hasta la muerte y "muerte de cruz" como su Mesías (Filipenses 2: 8) y no con tristeza sino con alegría (Mateo 5: 11-12; Filipenses 4: 4). Es cada vez más conocido el texto de Ignacio, discípulo del apóstol Juan, obispo de Antioquía (año 107):

"Por lo que a mí toca, escribo a todas las Iglesias, y a todas les encarezco que yo estoy pronto a morir de buena gana por Dios, con tal que vosotros no me lo impidáis. Yo os suplico: no mostréis para conmigo una benevolencia inoportuna. Permitidme ser pasto de las fieras, por las que me es dado alcanzar a Dios. Trigo soy de Dios, y por los dientes de las fieras he de ser molido, a fin de ser presentado como limpio pan de Cristo (...). Cuando el mundo no vea ya ni mi cuerpo, entonces seré verdadero discípulo de Jesucristo. Suplicad a Cristo por mí, para que por esos instrumentos logre ser sacrificio para Dios" (Ignacio, Carta a los Romanos, cap. 4: 1-2).

La confianza cristiana está sostenida en una promesa de Cristo que llama a sus verdaderos seguidores "bienaventurados" (felices) con anticipación. Para el cristiano es evidente que no existen garantías mientras se está en el mundo. Pero Dios enviará al Espíritu Santo para consolarlos (Juan 14: 26). Para el seguidor de Jesús, la palabra de Dios es una garantía cuando el salmista dice: "Espera en Yahvé, sé fuerte, ten ánimo, espera en Yahvé" (Salmos 27: 14). Hay una confianza fundamental de todo cristiano que no comprende del todo tanta enseñanza aun acercándose a las escrituras, porque los pensamientos de Dios son insondables (Isaías 55: 8-9; Romanos 11:33) y su voluntad difícil de entender (Juan 6: 60), pero Dios se manifiesta en Cristo en tanto es Verbo de Dios y, Pedro sabe que puede confiar en Cristo porque lo ha conocido de cerca y puede decir con palabras de un pescador humilde: "Señor, ¿a quién vamos a ir? Tú tienes palabras de vida eterna" (Juan 6: 68).

La fe del cristiano va más allá de creer en dogmas. Es necesario también vivir como Jesús en quien ha puesto toda su confianza, como un niño que está seguro en la nave porque sabe que su padre es quien va al timón. Se trata de una confianza básica que ya está descrita en el neo-psicoanálisis de Erik Erikson. Él plantea 
una teoría que otorga mayor poder al yo que al ello freudiano. Brindó al solitario individuo del psicoanálisis no solo vínculos con figuras significativas de su familia sino además contexto familiar en sentido histórico cultural. La situación de inseguridad del bebé durante su primer año de vida es de total dependencia y los padres se convierten en su seguridad. Es el origen de la experiencia de solidaridad que Adler ya había visualizado como el origen del sentimiento comunitario. Si las relaciones con las figuras significativas no cubren las carencias del niño en esta etapa se inicia la desconfianza básica que en el Análisis Transaccional será la base de la "Posición Existencial" nihilista o fútil. Me pregunto ¿Qué tan importante será la imagen materno/paterna en la futura aceptación de una figura protectora como es Dios? Es posible que una persona, cuando estructura inconscientemente su vida desde la postura existencial desvalorizada (yo estoy mal y tú estás mal), tenga serias dificultades para interiorizar la imagen amorosa de un "Dios-Padre":

La confianza y la desconfianza tienen, pues, un origen social en la relación entre hijo y madre/padre, que es "un intercambio afectivo de sentimientos no estructurados pero confluyentes, los cuales crean un clima afectivo entre las dos partes interesadas" (...). Confianza $y$ desconfianza son, se entiende, rasgos sociales $y$, como tales, definen todo comportamiento posterior... (León y Zambrano, 2000 p. 36).

La confianza básica asociada a una imagen de Dios Padre/Madre, que acepta y ama incondicionalmente al hombre (primariohedonista $y$ secundario-normativo) que somos, da como resultado la ampliación del sentido lúdico (placer de la norma) en el cual se maximiza el campo visual del sentido del humor. Erikson se refirió a un origen social de la experiencia primaria de confianza y el sentido del humor solo puede madurar en el conocimiento de uno mismo. Solo podemos ser expertos en nosotros mismos a través de experiencias de otredad. El sentido del humor no puede surgir sin la capacidad desarrollada $e$ inteligente para empatizar con los demás. El humor es esencialmente capacidad de "compasión" (sentir con el otro) que se puede ampliar a todo lo animado e inanimado. Esta capacidad para estar en sintonía con el mundo es, en el fondo, un sentimiento vitalista en el cual los objetos del mundo quedan aceptados, a pesar de las deficiencias y mediocridades propias de la realidad en la cual nos ha tocado vivir. Por eso, Lersch (1974) cita a O. J. Bierbaum para afirmar que "Humor es reír a pesar de todo", y dice además algo relativo a la fe:

... el núcleo esencial más profundo del humor radica en la fuerza de la vivencia religiosa. El humor ve lo terrenal y lo humano en su insuficiencia respecto a Dios. Pero lo ve desde su sentimiento mundano en el espejo del amor que Dios profesa a su Creación, sin que por ello tenga que hablar de Dios ni hacer teología. Habla en nombre de la resignación derivada del conocimiento de que todo lo terrenal y humano es incompleto. Pero esta misma resignación es a su vez asumida, también como algo terrenal y humano, en la certeza de que todo lo finito está amparado en la misericordia de Dios. Según esto, el humor es amor $y$ piedad hacia el mundo, precisamente alli donde este muestra sus defectos, su insensatez e incluso su maldad (...). Ama al mundo a pesar de su imperfección, precisamente por ser lo que es, del mismo modo que ama a las sombras por causa de la luz que las produce. Pero el amor es siempre un "decir que sí" a todo lo que es, y una alegría por el hecho de que sea. Por eso, el amor mundano del humor es también, al mismo tiempo, alegría cósmica, gratitud hacia Dios por concedernos vivir en este mundo imperfecto (Lersch, 1974 p.p. 308-309).

La imagen inaugural del cristianismo es un Salvador (Jesucristo) que viene en forma de bebé no solo incapaz de andar por sí mismo, además de eso, pobre. Lo tiene todo sin embargo. Una mamá y un papá que lo quieren y que hacen lo mejor de sus esfuerzos para que no esté expuesto a frío y a la persecución de Herodes. Ya desde el inicio, Cristo tenía problemas con los poderosos de su tiempo 
y no pasó mucho para terminar en una cruz muriendo de a pocos junto con dos ladrones. Los soldados romanos no podían evitar burlarse de un rey judío que a lo más podía montar un burrito (Mateo 21: 2). Y Cristo hasta al final sigue compasivo y le dice a su "Papá" (Abba) que perdone la ignorancia de sus hermanos menores (Lucas 23: 34). La vida de Cristo "el Salvador" terminó, a los ojos del mundo, como la vida de un payaso que pagó caro por su gracia. Su discurso era incómodo para los equilibrados que estaban seguros con sus rituales de salvación y sus contribuciones al emperador. Jesucristo no era un diplomático ni un calculador de conducta higiénica. Su discurso "frontal" y "radical" sobre el amor divino ponía nervioso a los grupos que se creían elegidos por Dios. Su pedagogía era con el ejemplo, con los hechos. No lo seguían los ilustrados de su tiempo, mayormente era gente humilde que no estudiaba su conducta sino que lo seguía por su carisma. A veces decía cosas tan desagradables que ponía en riesgo la cantidad de sus amistades. Una vez se le ocurrió decir que era un "pan comestible" aun a costa de perder a muchos discípulos (Juan 6: 52-66). Sentido del humor es darle poder a Pedro a sabiendas que lo negará en el momento difícil y lo que es peor, darle poder de "atar y desatar" (Mateo 16: 19) a un sujeto al que luego llamará "Satanás" (Marcos 8: 33). También es "sentido del humor" (compasión) que Jesús resucitado conceda el Espíritu Santo a sus discípulos y con ello les autorice a "perdonar y retener pecados" (Juan 20: 22-23). Sí, son doce apóstoles, pobretones e imperfectos y con ellos va un traicionero. A pesar de todo, ellos tienen el poder de perdonar en el nombre de Dios.

\section{Confesión sacramental como terapia fundamental}

El deseo de reparar un hecho es parte de la tendencia humana que Lersch (1974) describe como "venganza": quien ha hecho daño, a cambio, también debe experimentar daño proporcional. El ajuste de cuentas se debe a que existe una necesidad compensatoria del ser humano cada vez que las vivencias pulsionales del yo individual quedan frustradas en su objetivo. El cristianismo procura frenar esta tendencia del yo individual que ya está presente de modo notorio en el mundo de los primates (De Waal, 1997). Por el contrario alienta la "revancha positiva" (socializada) que denominamos "gratitud". Sin embargo, hay hechos en la vida que no se pueden reparar y generan por ello frustración. La persona frustrada se critica y experimenta fuerte necesidad de dirigir su propia crítica en contra de otros. Las conductas que comúnmente denominamos "mal intencionadas" pueden tener su gestación en un sujeto que recibió potentes mensajes de muerte a nivel no consciente y débiles "caricias positivas incondicionales" (afecto incondicional). El sujeto que experimenta fuerte crítica interna sin embargo tiene suficiente grado de libertad y no se puede exonerar de su responsabilidad moral. Necesitará entonces de nuevos contextos sociales para potenciar su coeficiente de amor propio. El desarrollo del sentido del humor puede servir para reconocer la experiencia de uno mismo como imperfecto en un mundo imperfecto en donde cabe estar agradecidos unos con otros.

Cuando aquello que no podemos reparar lleva consigo desaprobación social internalizada, experimentamos "vergüenza", que es la conciencia de inferioridad al quedar uno expuesto y sin posibilidad de salida ante los demás. El sentimiento de vergüenza no puede repararlasituación porquequien lo experimenta se siente no solo expuesto y sin posibilidad de desplazamiento sino socialmente acorralado: en el temor se toma distancia, en el miedo se retrocede, el susto paraliza, y en la vergüenza el individuo quiere desaparecer de la mirada ajena a tal punto de quedar sin escapatoria ante su propia mirada. La vergüenza atenta contra la autoestima (Lersch, 1974). Una cosa es el sentimiento de pudor y la actitud de discreción y otra el sentimiento reiterado de vergüenza. Quien experimenta vergüenza suele estar muy atento a la opinión ajena y en cierto sentido depende de esa opinión más que de la propia. La vergüenza como rasgo psicológico implica una estructura de relaciones simbióticas en la cual el sujeto encuentra cómodo presentarse como disminuido, o en su defecto, resentido con los demás para no responsabilizarse de sus propias decisiones. 
El cristianismo ofrece recursos humorísticos de importancia terapéutica. En algún modo, presenta a su Dios como un "Cristo-payaso" (Marcos 15: 17-19) que viene a salvar a su pueblo de la esclavitud espiritual (Lucas 20: 25; Juan 18: 36) pero solo viene acompañado de un grupo de pescadores que piensan todavía en privilegios humanos (Mateo 20: 21). Es pedagógica esta imagen de Cristo-Dios, el único bueno, que es tratado en serio como a un delincuente y en tono de burla como a un Dios. En el proceso de "perfección cristiana" el creyente arrepentido se da cuenta que no es él quien queda desfigurado por el pecado sino el agraviado de esta historia, Jesucristo. No es pecado sino prejuicio creer que uno queda mal contando su pecado porque está "manchado", cuando es todo lo contrario. El manchado es el rostro de Cristo cada vez que uno ofende a su prójimo (Mateo 24: 40). He ahí la terapia fundamental, aquella que realiza un "giro copernicano" en la concepción vindicativa del ser humano. Ya no se trata de la propia imagen sino de la imagen de Cristo crucificado. Ya no se trata de la propia vida sino de Cristo como lo primero en la vida: "El que encuentre su vida, la perderá; y el que pierda su vida por mí, la encontrará" (Mateo 10: 39). La vergüenza es una emoción entendible desde la perspectiva humana. Se trata de una vivencia que nos avisa no solo de una pérdida como la tristeza o de la pérdida del propio prestigio (que también apena y no siempre avergüenza) sino del menoscabo de la propia autoestima que nos desagrada a la vista del otro (Lersch, 1974). No se trata entonces de ser un "sinvergüenza" sino de comprender que desde la perspectiva del cristiano los intereses del yo respecto a su propia imagen quedan de todo menos absolutizados.

Cristo, el único cristiano bueno, sale adelante y se deja ver vulnerable. Entonces le enseña al cristiano que lo mejor que tiene (Cristo) ya fue humilladoy que el próximoquehacer en adelante será completar con viva fe su sufrimiento (Colosenses 1: 24) para salir transfigurados con él (Filipenses 3: 21). El problema de autoestima queda entonces trastornado por el cambio cristiano de papeles (Gálatas 2: 20). El arrepentimiento, por el contrario, sí está en la mira de la vida cristiana porque se trata de un sentimiento que requiere la sinceridad con uno mismo. En el arrepentimiento no está en juego la percepción de los demás como en la vergüenza sino la conciencia de haber fracasado (vulnerabilidad del yo mismo) en tanto hemos sido capaces de tal acción (Lersch, 1974). El arrepentimiento es importante para conocer nuestros límites, nos vuelve humildes para ya no sobrevalorar el yo individual. Es entonces un camino que abre las puertas a la trascendencia:

"Para el arrepentimiento no es realmente esencial la disposición a la reparación, pues esto en muchos casos es absolutamente imposible, sino la disposición para llegar a ser otro hombre" (Lersch, 1974 p. 219).

El sacramento de la reconciliación tiene por objetivo al "hombre nuevo" (Efesios 4: 24). Por eso necesita de un hombre arrepentido y de un Dios que perdona sinceramente. El sacerdote presencia el encuentro del hombre con el amor divino que lo convierte en una especie de "médium" o "puente" que re-presenta por medio de signos el perdón que Dios ofrece de modo indefinido a sus creaturas. La religión, que es en esencia "reunión con Dios", no solo es para el cristiano dogmas con reglas morales y rituales de culto en pro de la salvación individual. El sacramento de la reconciliación se manifiesta como una relación personal tan íntima que paradójicamente no puede dejar de abarcar su acción en los demás. El encuentro con Dios misteriosamente se expresa como uno y comunidad (tri-unidad) y se representa en cada uno transformándolo en miembro de un solo cuerpo (1 Corintios 12: 27). En el cristianismo, cada individuo tiende a la "despersonalización", término que tiene pleno sentido cuando lo asociamos, no al manual psiquiátrico, sino al mundo de la fe y de la gracia divina. Cada creyente es como parte del rompecabezas del rostro de Dios que se hace visible en Jesucristo, su imagen perfecta. El sacerdocio de cada cristiano (1 Pedro 2: 9) se "reviste" en el presbítero (anciano) que a su vez realiza el gesto de salvación por excelencia en la absolución de toda ofensa en contra de Dios que se rebela principalmente en cada transgresión al cuerpo místico de Cristo.

El humano escucha el pecado de su hermano y lo que él mismo no puede perdonar queda 
perdonado por medio de su gesto sensible. Este acto tiene carácter mágico desde la óptica naturalista y cientificista de la actualidad. Sin embargo, no es un espectáculo ni algún rito del "superior-perfecto" hacia el "inferior-imperfecto". En realidad se trata del encuentro entre "dos perfectibles" (Mateo 5: 48) que se reúnen en el nombre del "único bueno" (Marcos 10: 18). El sacramento de la confesión sigue siendo una representación de la colectividad que se realiza en secreto como unidad misteriosa. Todo cristiano está llamado a continuar la historia de la salvación siendo cómplice de la gracia divina que escapa a las posibilidades de comprensión para dar sitio a la fe. Lo que se deja ver es lo sencillo, lo psicológico del arrepentimiento y de la fuerza que se obtiene al saberse reconciliado con Dios y con el prójimo. El sacerdote no solo media el perdón divino en sentido unidireccional sino que también expresa con su humanidad imperfecta el "humor de Dios" que se resume en la compasión que Yahvé tiene hacia sus creaturas y su ignorancia (Lucas 23: 34). Hombre y Dios (Jesús + Cristo) carga con los pecados de un mundo "delicado del corazón" (el yo profundo que acepta la injusticia) y miseria oculta. La persona del sacerdote no puede perdonar tanta ofensa pero lo hace Cristo "por medio" del sacerdote $y$, al mismo tiempo, el sacerdote es signo sensible de Dios que enseña con su revestimiento en Cristo a estar por Cristo, con él y en él. El sacerdote con su investidura se convierte en "pedagogo de la salvación".

Existe entonces una delegación de Dios al hombre como si el sentido de verbalizar la ofensa a Dios fuera a dar testimonio a otro desconocido (el sacerdote del pueblo de Dios) de la fe en el perdón divino $y$, al mismo tiempo, fe en el otro cuando se cree realmente que Dios se puede manifestar en cada hombre, miembro del cuerpo místico de Cristo. El sacerdote no es un privilegiado sino alguien que sirve a su comunidad mediante la prédica explícita y la administración de los sacramentos. Cada miembro de la iglesia (asamblea) participa del sacerdocio de Cristo y el sacerdote hace eficaz por medio de los sacramentos, el sacerdocio de cada uno en la vida cotidiana. El sacerdote es uno más con el pueblo de Dios pero su sacerdocio le otorga un poder exclusivo con requisitos físicos, psicológicos y espirituales. Así como la esposa se prepara para el amado, la iglesia penitente debe prepararse para su encuentro con Dios. El sacerdote necesita prepararse debidamente para saber administrar los sacramentos que son medios de salvación. El sacerdote se debe a la "iglesia" (asamblea) y no utiliza el sacerdocio para cubrir intereses personales (sanos o patológicos) o de un determinado grupo de "selectos" y "puros".

El cristiano tiene fe en que Dios transformará esta tierra imperfecta y la convertirá en un nuevo lugar para vivir en paz (Miqueas 4: 1-5). El "celibato" (abstención de vida conyugal) se fue consolidando a lo largo de siglos como una práctica de los primeros cristianos que se empezó a prescribir a la totalidad del clero católico en los sínodos de Ancira y Elvira a inicios del siglo IV, exigencia que no era seguida en todo lugar. Es el caso de la Iglesia oriental en donde se mantiene la forma tradicional de recibir el orden sagrado y tener vida marital (Lenzenweger y otros, 2006). El sacerdote de la Iglesia católica, con su celibato renuncia a los hijos y herederos por el Reino de los Cielos (Mateo 19: 12) y entonces inicia su kerigma (proclamación): promesa de la "salvación" (Lat. salvatio,-onis emparentada a "salud" (Lat. salus, -utis) que empieza a cumplirse de alguna forma en la vida terrena. Para Joseph Ratzinger (1997), hoy Benedicto XVI, el celibato tiene su prefigura en el Antiguo Testamento. Refiere que la tribu de Leví constituida por sacerdotes, a diferencia de las otras once tribus, no recibió tierras y tuvo como única herencia a Dios. En ese mismo sentido, el sacerdote católico, seguidor de Cristo (célibe y sin herederos) puede, con su decisión, dar testimonio de la esperanza cristiana que solo tiene a Dios por tierra y herencia:

Digo a Yahvé: "Tú eres mi Señor, mi bien, nada hay fuera de ti" (...). Yahvé es la parte de mi herencia y de mi copa, tú aseguras mi suerte: me ha tocado un lote precioso, me encanta mi heredad" (Salmos 16: 2-6). Para el magisterio de la Iglesia católica, el sacerdote con su testimonio de vida célibe está señalando el camino de fe en pos de una felicidad mayor y eterna (Salmo 16: 9-11). 
La terapéutica cristiana fundamental pasa por el ejercicio de la cercanía con el otro y de la importancia del secreto que refuerza la idea de que somos únicos ante Dios. Cada vida merece un espacio personal y un tiempo específico que Dios dedica a cada uno para escucharlo. Esta representación no es trivial. Trataron a Cristo con términos peyorativos, como a un payaso, lo maltrataron durante todo el proceso buscando que sea culpable a como dé lugar. Fue llevado a la fuerza y condenado injustamente a morir en una cruz. Se llevó consigo los pecados de la humanidad y con autoridad de Dios ahora pide que le sigan en un "camino estrecho" donde hay mucho por hacer (Mateo 8: 20). Ya no hay bienes materiales que interesen más que Dios (Mateo 6: 21). Mataron al "hermano mayor", al más bueno y mejor de los cristianos (Cristo). Dios ha permitido la bofetada en su rostro $y$ no ha mostrado ira. Ha conocido de cerca al humano en las calles Palestina y al tentador en el desierto. La religión entendida así es un acto de terapéutica fundamental que reestructura el yo y sus posibilidades de ser mejor a través del abandono en la confianza y en el amor que son formas de vivir el sentimiento comunitario o la afirmación de la posición existencial dialógica ("Yo estoy bien y tú estás bien") antes que vivir posturas súper-compensatorias $\mathrm{de}$ superioridad (rigidez, dogmatismo) o de inferioridad (sumisión ciega). Para los griegos "desmesura" (gr. hybris) es cuando una persona pretende ser menos o más de lo que realmente es. El cristianismo como terapia fundamental va más allá y atiende a lo "puede llegar a ser" fusionando su "máscara de actuación" (individuo y su rol) con la "máscara ritual" (comunidad festiva) del sacerdote para "celebrar" la gratuidad del amor divino.

\section{Conclusiones}

La psicoterapia transaccional y el teleoanálisis adleriano tienen capacidad para captar escenas importantes del fenómeno religioso dentro y fuera de la confesión sacramental debido a rasgos lúdicos que las caracterizan. El fenómeno religioso toca directa e íntimamente la conciencia del individuo y se convierte en una fuente de abundante normatividad. El fenómeno religioso se interioriza, a mi modo de ver, por medio de reglas que el niño asume de modo lúdico. En el juego está la clave de sus futuras relaciones de moralidad religiosa. Comúnmente, debido a su enseñanza como instrumento de control de conducta, suele incorporarse como una moral centrada en el premio-castigo. La norma moral se convierte así en un instrumento de poder. Tarde o temprano el sujeto queda desencantado porque interpreta el mundo normativo religioso como atentado contra sus intereses privados. El Análisis Transaccional muestra al detalle cómo se interiorizan diálogos internos rígidos que acompañan al patrón normativo-inconsciente de conductas autodestructivas. El teleoanálisis adleriano presenta una terapia flexible que concibe el sistema normativo consciente y el sistema hedónico inconsciente como complementarios para la autocapacitación del sí mismo personal. El teleoanálisis adleriano se constituye en terapéutica de flexibilización capaz de reorientar la religiosidad trastornada.

Toda experiencia religiosa, por más sobrenatural que sea, se realiza en el ser humano y es posible aproximarse a ella desde perspectivas científicas diferentes (teología, filosofía, arte, antropología, sociología, psicología y biología). La psicología, el consejo y la psicoterapia tienen lugar en cada experiencia sacramental que es precisamente un canal de comunicación entre lo mejor del ser humano y lo sagrado. Los sacramentos tienen componentes simbólicos y llevan consigo rituales de contenido afectivo que vinculan íntimamente al sujeto con la gracia de Dios. El sacramento de la confesión contiene escenas y gestos que incluso revelan formas fundamentales de terapia. Fundamentales en el sentido algo "nuclear". En la confesión sacramental se puede encontrar la síntesis de toda vida cristiana que se presume como vida humana llevada a su plenitud en Cristo, Dios y humano a la vez. En el confesionario se muestra cómo Dios se relaciona con el hombre que está imposibilitado de verlo cara a cara pero que lo capta en la figura de un hombre que se ha "revestido" de "Cristo" (imagen de Dios). Una escena que vista desde otras formas de lectura, es un acto teatral de máscaras. La confesión sacramental contiene un elemento lúdico y mágico que reúne las condiciones para 
interactuar con la norma moral que completa la figura de lo humano.

En tal escena ludo-terapéutica se pueden subordinar los temas restantes. También es indispensable entrar en contacto con la concepción del pecado, la vergüenza, el secreto, el arrepentimiento y el sentido de culpa como parte de la salud mental del cristiano. Convertirse a Dios no es quedar "perfecto" $e$ "impecable" sino quedar cada vez más intolerante con la idea de seguir desfigurando el rostro de Dios. La obra buena ya no es para obtener un beneficio y menos para evitar el castigo reservado para quienes juegan a ser dioses. Aquella es una fe y una moral infantil, regresiva y proclive a la neurosis. Por el contrario, las buenas obras son consecuencia del amor incondicional a Dios. El cristiano es fundamentalmente un porfiado que tiene la motivación para levantarse de inmediato luego de la caída. Sigue confiando en medio de sus limitaciones porque es consciente del amor que Dios tiene por el mundo de cada uno a pesar del amor humano, que en el fondo está expuesto a la conveniencia personal, las pasiones y a un pecado de origen que se vuelve operante en la posibilidad de ofender a Dios mientras se está vivo en cuerpo y en el mundo aun no transfigurados. Es por eso que el cristiano recurre a la gratuidad del amor divino que se da por medio del Espíritu Santo. En la psicoterapia, estamos constantemente alerta a los juegos y maniobras inconscientes detectables en el lenguaje verbal y corporal. $\mathrm{El}$ individuo neurótico puede manifestar problemas psicosomáticos, e incluso, crear fenómenos parapsicológicos que en buena cuenta podemos controlar. $\mathrm{El}$ hombre "normal" constantemente está expuesto a la acción de la restricción de la información que le otorga poder para lograr objetivos de vida. Sin embargo, hay relaciones de poder exageradas por diversas carencias afectivas que se convierten en lugar propicio de "espíritus del mal" (Efesios 6: 12). El líquido amniótico de la patología es el autoengaño que hay en toda simbiosis y el alimento de todo pecado es la mentira. De tal modo que tanto el psicoterapeuta como el director de almas pueden detectar, cada uno en su ámbito, el sector de la patología y el momento de la acción enemiga. En el segundo caso, frecuente antes o después de la confesión, se requiere otro tipo recursos de discernimiento para identificar la acción del "espíritu de la envidia" que está detrás de personas y situaciones con un fin específico: alejar al cristiano de Cristo. En el lenguaje artístico del amor romántico, para el enamorado "estar lejos de su amada es como un castigo y no ser correspondido es como un infierno". El proceder demoníaco, progresivamente mueve fichas y según las fuerzas de cada quien opera engaño para dejar al sujeto lejos de la gracia divina. Una sociedad sin Dios y con infinidad de diosecillos bailando en cada pantalla del mundo virtual es fácil presa de patologías colectivas.

En el sacramento de la reconciliación, el secreto y el silencio son fundamentales. El desierto era el lugar predilecto de un Cristo que normalmente estaba rodeado de amigos y discípulos. Él quería de especial manera a los pequeños, a los sencillos, a los que no están en la contienda por dinero o por un puesto de trabajo; él quiso a los que reían por pura alegría $y$ sin premeditaciones. La muchedumbre lo seguía por sus milagros pero él quería que los niños se le acerquen porque para ellos cada momento era como un milagro tenerlo cerca. La magia estaba en una broma y la ilusión era pan de cada día. El adulto y sobre todo el sabio de entonces, por lo general, estaban para cuestionar cada "imposible pretensión de Jesús" (Lucas 5: 21; Juan 6: 52), porque solamente era el hijo de un carpintero (Mateo 13: 54-56).

Jesús también fue tentado a pecar gravemente contra la voluntad de su "Papá" (Dios). La tentación consistió en la acción del "demonio espectacular" que intentaba hacerle caer al procurar que "demuestre" su poder de hacer grandes milagros. Solicitud a la que Cristo no hizo caso hasta que su madre le persuadió de lo contrario por motivo de escases durante una boda (Juan 2: 1-5). Su mamá había adelantado el tiempo de la manifestación. Cristo dejó que los humanos (sus padres, amigos y hermanos) sean parte de sus mejores momentos. San José revela el lado silencioso de Jesús. El silencio y el desierto desenmascaran más rápido al mundo. Para el cristiano católico, la confesión 
se realiza en secreto. Este es el primer "lugar" del acontecimiento religioso. Para confesar los pecados se requiere del silencio mental que permite evaluar los actos incompatibles respecto al amor divino.

Dios perdona y transforma la vida de pecado en vida cristiana. La nueva vida predispone al amor incondicional que es lo contrario al pecado, que en esencia es odio a uno mismo que se revela en la comunidad, afectándola. El cuerpo de Cristo (la Iglesia) se regenera respetando la libertad de cada uno de acercarse o lo contrario. El creyente sabe que Cristo pasa y aprovecha, ante todos pero en silencio, la oportunidad de su cercanía, como en el caso de la hemorroisa (Marcos 5: 27-28). Tocar el manto nuevamente es un gesto vivo de como Cristo gusta de la mediación. Cristo cura y perdona. El sacerdote es un vehículo querido de Dios para representar lo divino y por eso también lo más humano y empático: el perdón. No es el trato de un superior que perdona a un subalterno sino que es el perdón de un padre hacia su hijo por medio de un hermano imperfecto. La confesión es un sacramento porque resume por medio de la absolución (oración y bendición con el signo de la cruz) el perdón de Dios. Implica confianza en el perdón divino y gestos sensibles desde una persona pecadora (pero no corrupta) a quien se le ha encomendado la función de representar a Cristo que acoge a quien sufre por no haber puesto a Dios en el primer lugar de su vida.

Cuando el hombre peca ofende a Dios no porque le haga daño. Ofende a Dios porque se aleja de aquello que no puede alcanzar con sus propios medios: la verdad. Vivir en Cristo equivale a vivir en verdad (Juan 14: 6). Pecar es alejarse del amor incondicional de Dios o dejar la posibilidad de alejarse de quien realmente le ama sin reserva. Se ofende a Dios cuando el humano se hace daño al creer que es posible vivir sin Él. El infierno empieza en la decisión libre de alejarse de su voluntad y se concreta definitivamente cuando Dios, que conoce las verdaderas intenciones, respeta la decisión de cada uno fuera del tiempo (eternidad). Decíamos en otro lugar que cuando alguno peca no queda manchado sino que insiste en maltratar el cuerpo del crucificado $y$ misteriosamente también el cuerpo de cada hermano porque cada cristiano es uno solo en Cristo. De ahí la necesidad de recibir el perdón solo luego de haberse reconciliado con sus hermanos (Mateo 5: 24).

Cuando verbalizamos nuestro pecado, estamos frente a otro que escucha nuestro dolor ante el hecho de haber actuado por debajo de nuestras posibilidades de amor. El sacerdote es también parte de una catarsis del penitente y necesita saber cuándo intervenir para consolar o cuándo callar como parte de un consuelo más eficaz. Cristo atiende por medio del sacerdote, atiende al que viene con el corazón dispuesto a dar testimonio del perdón de Dios. El penitente da testimonio ante la comunidad que está dibujada en él sacerdote falible y también necesitado de Cristo. Se apoyan mutuamente (sacerdote laico y sacerdote clérigo) para ser hombres y mujeres según Dios y no según las pasiones humanas como, por ejemplo, ansia de notoriedad o afán de lucro. La confesión es entonces un trato espiritual pero además es una especie de cura psíquica indirecta. Nuestro cuerpo no solo queda espiritualizado por las obras de fe sino que Dios mismo permite que el hombre se mimetice de modo íntimo con el misterio trinitario de común unidad.

La experiencia del perdón no pasa entonces por sentirse "puro" o "privilegiado" que tampoco es un grave problema psicológico. Lo que ocurre en el perdón es una acción divina imposible desde la óptica de quien no conoce la pedagogía divina de los signos sensibles (Lucas 5: 21). Dios opera por medio de su sacerdote (Cristo) y perdona ciertamente todo pecado recordado o no. Es una acción simple en apariencia, casi mágica e imposible a los ojos de quien ha pecado y que experimenta su ofensa como difícil de no repetir en lo secreto, como ocurre con toda pasión humana. El pecado que afirma los intereses del ego individual es más atractivo que agradar a un Dios cano sobre su nube blanca, rodeado de cuatro querubines allá en las alturas. Cuando en realidad Cristo ofrece la terapia (cura y soporte) fundamental del reconocimiento de cada uno como importante a pesar de la mediocridad del ego. Invita al arrepentido, que miraba con embriaguez su vida de pecado 
(intereses de prestigio $\mathrm{y}$ otras pasiones), a reconocer que se trataba de monedas de un céntimo al lado de estar en paz con un Dios al que solo cabe estarle infinitamente agradecido por el simple hecho de vivir. Entonces, cada acercamiento al confesionario es un testimonio de amor a Cristo. El cristiano que puede participar en la eucaristía se parece un poco al hermano del hijo pródigo porque cuenta con la cercanía del papá. El que se confiesa, purgatoriamente espera el gran momento y piensa en su vida lejos del padre a quien extraña. No le interesa vencer entonces alguna vergüenza de contar su pecado. Sabe que no está defendiendo su autoestima ni su salvación eterna, al menos de modo interesado. Está allí, a un lado, para ser un hombre nuevo en Cristo. Espera su turno de confesión, sin privilegios, para defender la causa de Dios por medio de su arrepentimiento.

¿Cuál es la causa de Dios? Creo que, en lenguaje cristiano, es vivir con dignidad durante el trecho que se le ha concedido al humano habitar en el cuerpo y vivir para siempre en la plenitud del amor. La primera parte de esta causa es tema de la psicoterapia y de todo intento sincero por cuidar de la vida. Allí, puedo visualizar la psicoterapia enseñando a pensar con autonomía y mostrando nuevas alternativas de autoprotección y permiso para disfrutar. Veo, además, a la psicoterapia enseñando acerca de los caminos de la risa y el sentido del humor. El humor es terapéutico porque ya en su inicio es una abdicación al esfuerzo casi obsesivo por el éxito y el afán del yo por tener el control directo o indirecto de los demás. El desarrollo del sentido del humor es una forma de terapia fundamental porque no solo desenmascara sino que enseña a quitarnos la máscara al mismo tiempo. El confesionario es paradójico porque siendo lugar de asuntos morales y de vergüenza, refleja, sin embargo, su aspecto lúdico (terapéutico) en el acto del juego básico de juntar a dos humanos imperfectos para transformarse mágicamente de penitente en "otro hombre" y de sacerdote "en Cristo" que absuelve de toda culpa y que regala su paz. Con ello no pretendo reducir el sacramento a categoría de "magia" sino que reconozco el fondo lúdico que hay en la experiencia que se realiza en el confesionario.

A pesar de todo lo imperfecto que rodea a este sacramento, el cristiano termina de nuevo dentro de esa casita de madera para encontrarse con lo que estima "más sagrado" por medio de un pecador como él pero "revestido" para olvidar su propia imagen y para volver a empezar juntos el recorrido al cielo de los justos. Vuelven quienes ya no "juegan al personaje" burlesco, escéptico y autosuficiente y que todavía tienen capacidad para reír de sí mismos. El sentido de la terapia fundamental implícito en la confesión sacramental, es poner a un lado la propia imagen con máscara incluida y atender sin demora al rostro desfigurado de Dios. La psicoterapia transaccional y el teleoanálisis adleriano tienen suficiente capacidad lúdica como para ampliar el coeficiente de humor requerido en este enfoque de la vida cristiana. 


\section{REFERENCIAS}

Adler, A. (1970) El sentido de la vida. Barcelona: Ed. Luis Miracle.

Allport, G. (1986) La personalidad. Su configuración y desarrollo. Barcelona Ed. Herder.

Auer, H. (1990) Psicología humanística. Módulos de psicoterapia. Lima: UNIFÉ.

Auer. H. (1997) Psicología humanística. Módulos de psicoterapia. Tomo 1. Lima: UNIFÉ.

Berne, E. (1975) Juegos en que participamos. Sicología de las relaciones humanas. México: Ed. Diana.

Nueva Biblia de Jerusalén (1998) Dirección: José Ángel Ubieta López. "Introducción a los evangelios sinópticos” p. 1412. Bilbao: Ed. Desclée De Brouwer.

De Waal, F. (1997) Bien natural. Los orígenes del bien y del mal en los humanos y otros animales. Barcelona: Ed. Herder.

Díaz Mateos, M. (1996) El sacramento del pan. Centro de Espiritualidad Ignaciana. Lima: Ed. Centro de Estudios y publicaciones.

Edwards, G. (2011) El triángulo dramático de Karpman. Como trascender los roles de perseguidor, salvador o de víctima. Madrid: Ed. Gaia.

Ellis, A. (1990) Manual de Terapia Racional-Emotiva. Volumen 2. Bilbao: Ed. Desclée De Brouwer.

Frankl, V. (1990) Logoterapia y Análisis Existencial. Textos de cinco décadas. Barcelona: Editorial Herder.

Hazán, Y. y Titze, M. (2011) Fundamentos de psicología profunda teleológica. Montevideo: Ed. Psicolibros.

Junchaya, R. (1985) No es tu destino, es tu programación. El ABC. Lima: Coperat.

Kertész, R. (2010) Análisis Transaccional Integrado. Buenos Aires: Ed. UFLO.

Lenzenweger, J. y otros. (2006) Historia de la Iglesia católica. Barcelona: Ed. Herder

León, R. y Zambrano, A. (2000) El hombre y la historia en Erik H. Erikson. Lima: URP

Lersch, Ph. (1974) La estructura de la personalidad. Barcelona: Ed. Scientia.

Pikaza, X. y Aya, A. (2009) Diccionario de las tres religiones: judaísmo, cristianismo, islam. Navarra: Ed. Verbo Divino.

Quitmann, H. (1989) Psicología humanística. Conceptos fundamentales y transfondo histórico. Barcelona: Ed. Herder.

Ratzinger, J. (1997) La sal de la tierra. Cristianismo e Iglesia católica ante el nuevo milenio. Madrid: Ed. Palabra. 
Royo Marín, A. (1996) La fe de la Iglesia. Madrid: Ed. Biblioteca de Autores Cristianos.

Ruíz Bueno, D. (1979) Los padres apostólicos. Edición bilingüe completa. Madrid: Ed. Biblioteca de Autores Cristianos.

Spitz, R. (1981) El primer año de vida del niño. Madrid: Ed. Aguilar.

Steiner, C. (2009) El otro lado del poder. Sevilla: Ed. Jeder.

Sullivan. H. (1964) La teoría interpersonal de la psiquiatría. Buenos Aires: Ed. Psique.

Titze, M. (1983) Fundamentos del Teleoanálisis adleriano. Barcelona: Ed. Herder.

Widengren, G. (1976) Fenomenología de la religión. Madrid: Ed. Cristiandad.

Young, J. y Klosko, J. (2001) Reinventa tu vida. Cómo superar las actitudes negativas y sentirse bien de nuevo. México: Ed. Paidós.

Young, J. y otros (2013) Terapia de esquemas. Guía práctica. Bilbao: Ed. Desclée De Brouwer.

\section{Texto bíblico utilizado para las citas del artículo}

Biblia de Jerusalén Latinoamericana (2016) Coordinador: Santiago García. Bilbao: Ed. Desclée De Brouwer.

\section{Referencias terminológicas tomadas de la red}

Sobre el acrónimo de Cristo (p. 27):

https://es.wikipedia.org/wiki/Ichthys Recuperado 07 - 08 - 17

Etimología de "salvación". Diccionario de la lengua española - Real Academia Española. (p. 33): http://dle.rae.es/?id=X7oZFdR Recuperado 15 - 08 - 17

Etimología de "desmesura" (p. 34)

http://etimologias.dechile.net/?hybris Recuperado 15 - 08 - 17

\section{Imágenes}

Pintura de "El Buen Pastor" (p. 17). Tomada de:

http://sacredimages.tumblr.com/post/21987919785/good-shepherd-01

Pintura de "Cristo expulsando a los mercaderes del templo" (p. 22). Tomada de:

http://infocatolica.com/blog/coradcor.php/1103111122-ique-hubiera-hecho-cristo-con

Fecha de recepción: 02-10-17

Fecha de aceptación: 28-11-17 
